NASA/TM-1996-107142/REV1

ARL-MR-294
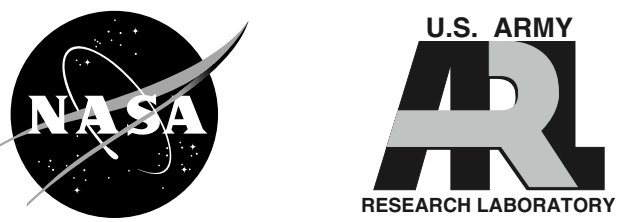

AIAA-96-0934

\title{
A Study of Large Droplet Ice Accretions in the NASA Glenn IRT at Near-Freezing Conditions
}

Dean R. Miller and Harold E. Addy, Jr.

Glenn Research Center, Cleveland, Ohio

Robert F. Ide

U.S. Army Research Laboratory, Glenn Research Center, Cleveland, Ohio 
Since its founding, NASA has been dedicated to the advancement of aeronautics and space science. The NASA Scientific and Technical Information (STI) Program Office plays a key part in helping NASA maintain this important role.

The NASA STI Program Office is operated by Langley Research Center, the Lead Center for NASA's scientific and technical information. The NASA STI Program Office provides access to the NASA STI Database, the largest collection of aeronautical and space science STI in the world. The Program Office is also NASA's institutional mechanism for disseminating the results of its research and development activities. These results are published by NASA in the NASA STI Report Series, which includes the following report types:

- $\quad$ TECHNICAL PUBLICATION. Reports of completed research or a major significant phase of research that present the results of NASA programs and include extensive data or theoretical analysis. Includes compilations of significant scientific and technical data and information deemed to be of continuing reference value. NASA's counterpart of peerreviewed formal professional papers but has less stringent limitations on manuscript length and extent of graphic presentations.

- TECHNICAL MEMORANDUM. Scientific and technical findings that are preliminary or of specialized interest, e.g., quick release reports, working papers, and bibliographies that contain minimal annotation. Does not contain extensive analysis.

- CONTRACTOR REPORT. Scientific and technical findings by NASA-sponsored contractors and grantees.
- CONFERENCE PUBLICATION. Collected papers from scientific and technical conferences, symposia, seminars, or other meetings sponsored or cosponsored by NASA.

- SPECIAL PUBLICATION. Scientific, technical, or historical information from NASA programs, projects, and missions, often concerned with subjects having substantial public interest.

- TECHNICAL TRANSLATION. Englishlanguage translations of foreign scientific and technical material pertinent to NASA's mission.

Specialized services that complement the STI Program Office's diverse offerings include creating custom thesauri, building customized databases, organizing and publishing research results ... even providing videos.

For more information about the NASA STI Program Office, see the following:

- Access the NASA STI Program Home Page at http://www.sti.nasa.gov

- E-mail your question via the Internet to help@sti.nasa.gov

- Fax your question to the NASA Access Help Desk at 301-621-0134

- Telephone the NASA Access Help Desk at 301-621-0390

- Write to:

NASA Access Help Desk

NASA Center for AeroSpace Information 7121 Standard Drive

Hanover, MD 21076 
NASA/TM-1996-107142/REV1

ARL-MR-294
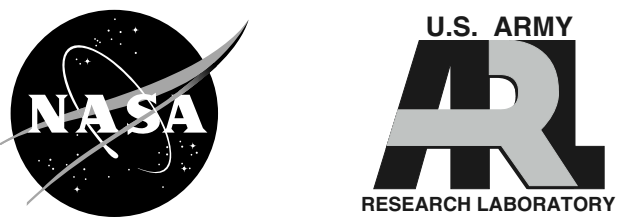

AIAA-96-0934

\section{A Study of Large Droplet Ice Accretions in the NASA Glenn IRT at Near-Freezing Conditions}

Dean R. Miller and Harold E. Addy, Jr.

Glenn Research Center, Cleveland, Ohio

Robert F. Ide

U.S. Army Research Laboratory, Glenn Research Center, Cleveland, Ohio

Prepared for the

34th Aerospace Sciences Meeting and Exhibit

sponsored by the American Society of Aeronautics and Astronautics

Reno, Nevada, January 15-18, 1996

National Aeronautics and

Space Administration

Glenn Research Center 


\section{Document Change History}

This printing, numbered as NASA/TM-1996-107142/REV1, June 2005, replaces the previous version, NASA Technical Memorandum 107142, January 1996, in its entirety. It contains the following change:

Figure 1 has been modified to make the document compliant with "NASA Internet Publishing Content Guidelines," NASA Information Technology Requirement NITR-2810-3.

Note that at the time of writing, the NASA Lewis Research Center was undergoing a name change to the

NASA John H. Glenn Research Center at Lewis Field. Both names may appear in this report.

Available from

NASA Center for Aerospace Information 7121 Standard Drive

Hanover, MD 21076
National Technical Information Service 5285 Port Royal Road Springfield, VA 22100 


\title{
A STUDY OF LARGE DROPLET ICE ACCRETIONS \\ IN THE NASA GLENN IRT \\ AT NEAR-FREEZING CONDITIONS
}

\author{
Dean Miller and Harold E. Addy, Jr. \\ National Aeronautics and Space Administration \\ Glenn Research Center \\ Cleveland, Ohio \\ Robert F. Ide \\ U.S. Army Research Laboratory \\ National Aeronautics and Space Administration \\ Glenn Research Center \\ Cleveland, Ohio
}

\begin{abstract}
This report documents the results of an experimental study on large droplet ice accretions which was conducted in the NASA-Lewis Icing Research Tunnel (IRT) with a full-scale 77.25 inch chord Twin-Otter wing section. This study was intended to: (1) document the existing capability of the IRT to produce a large droplet icing cloud, and (2) study the effect of various parameters on large droplet ice accretions.

Results are presented from a study of the IRT's capability to produce large droplets with MVD of $99 \mu \mathrm{m}$ and $160 \mu \mathrm{m}$. The effect of the initial water droplet temperature on the resultant ice accretion was studied for different initial spray bar air and water temperatures. The initial spray bar water temperature was found to have no discernible effect upon the large droplet ice accretions. Also, analytical and experimental results suggest that the water droplet temperature is very nearly the same as the tunnel ambient temperature, thus providing a realistic simulation of the large droplet natural icing condition.

The effect of temperature, droplet size, airspeed, angle-of-attack, flap setting and de-icer boot cycling time on ice accretion was studied, and will be discussed in this report. It was found that, in almost all of the cases studied, an ice ridge formed immediately aft of the active portion of the de-icer boot. This ridge was irregular in shape, varied in location, and was in some cases, discontinuous due to aerodynamic shedding.
\end{abstract}

\section{NOMENCLATURE}

c airfoil chord, inch

r cylinder radius, inch

t time, seconds

AOA Angle-of-attack, degrees

C $\quad 5.0 \times 10^{4}$

E Collection efficiency

FAR Federal aviation regulations

FSSP Forward scattering spectrometer probe

IRT Icing research tunnel

LWC Liquid water content, $\mathrm{g} / \mathrm{m}^{3}$

MVD Median volumetric diameter, $\mu \mathrm{m}$

OAP Optical array probe

T Temperature, ${ }^{\circ} \mathrm{F}$

V Airspeed, mph

$\begin{array}{lll} & & \text { Subscripts } \\ \text { a } & \text { air } & \\ \text { b } & \text { average } & \\ \text { d } & \text { droplet } & \\ \text { t } & \text { total } & \end{array}$

\section{INTRODUCTION}

Recent aircraft accidents have served to focus the attention of the icing community on the role that large droplets may have played in these accidents. It is possible that the combination of large droplet and near-freezing temperatures may have contributed to one commuter aircraft crash, and may also have been a factor in others. The fact that these droplets may impinge on the airfoil surface beyond the ice protected surfaces, or impinge within the protected zone and then slide aft before freezing is a concern. 
At the present time the icing database concerning large droplets at near-freezing temperatures is very limited. This is a result of several factors. First, these conditions occur infrequently when considered on a statistical basis. Secondly, if large droplet icing clouds are defined to have droplet distributions with Median Volumetric Diameter (MVD) ranging from 40 to $400 \mu \mathrm{m}$, then this condition falls outside the FAR-part 25 icing certification envelope. Typically, the emphasis in icing tunnels and icing flight programs has been on aircraft certification within the FAR-part 25 envelope, where icing cloud MVD's are less than $40 \mu \mathrm{m}$. Therefore, the icing tunnel or flight databases with this condition are very limited.

Given the fact that this combination of large droplet with near-freezing temperatures is an important issue for the icing community to deal with, the Icing Technology Branch at NASA-Lewis Research Center has attempted to study the large droplet phenomena. One goal of this effort is to increase the size of the existing database on large droplet ice accretions at near-freezing temperatures. To achieve this goal, the NASA-Lewis Icing Research Tunnel has been utilized to conduct experimental large droplet icing investigations.

The first experimental large droplet investigations at near-freezing temperatures were conducted in the NASA-Lewis Icing Research Tunnel (IRT) in December 1994, and also during May 1995. As a follow on to these investigations, another more comprehensive experimental investigation was conducted in the IRT during the last quarter of 1995. The primary objectives of this latter investigation were: (1) To document the existing capability of the IRT to produce icing clouds of large droplets at near freezing temperatures, and (2) To conduct a parametric study of large droplets at near-freezing temperatures on a commuter-class aircraft wing section, by varying temperature, droplet size, airspeed, angle-of-attack, flap-setting, and de-icer boot cycling time.

This experimental investigation of large droplet ice accretions was comprised of two tests, each one utilizing a different commuter-class aircraft wing section. The first test entry utilized a full-scale 77.25 inch chord Twin Otter wing section with a $30 \%$ chord flap. The second entry utilized a full-scale wing section with a NACA-23012 airfoil section, and a nominal chord length of 68 inches at half-span. Due to time constraints in reducing the data from the second test entry, only the results from the Twin Otter wing were available at the time of this writing. It is anticipated that the results from the second test entry with the NACA-23012 wing will be presented in a later report.

\section{FACILITY AND MODEL DESCRIPTION}

\section{Icing Research Tunnel}

The NASA IRT is a closed-loop refrigerated wind tunnel. The test section is $6 \mathrm{ft}$ high and $9 \mathrm{ft}$ wide, and contains a turntable assembly which allows for model angle-of-attack changes. A $5000 \mathrm{hp}$ fan provides airspeeds up to $400 \mathrm{mph}$ (empty test section). The refrigeration heat exchanger can control the air temperature from $+40^{\circ} \mathrm{F}$ to $-40^{\circ} \mathrm{F}$. The water spray system is capable of simulating icing clouds with MVD of 14 to $40 \mu \mathrm{m}$, and Liquid Water Content (LWC) of $0.3-3.0 \mathrm{~g} / \mathrm{m}^{3}$. Figure 1 shows a schematic view of the IRT.

\section{Icing Cloud Spray System}

The spray system that generates the icing cloud in the IRT is composed of eight spraybars containing a total of 95 spray nozzles. The spraybars are located in the settling chamber upstream of the contraction section as shown in Figure 1. The spray nozzles used are airassist type atomizers which are not commercially available but are specially built for NASA. A crosssectional view of the nozzle is shown in Figure 2.

Two types of nozzles are currently utilized in the IRT spray system and are designated Standard and Mod-1. The Mod-1 nozzles were used for the large droplet tests described in this report. This is because they produce LWC levels closer to those expected for large droplets in natural icing clouds, than do the Standard nozzles. The Mod-1 nozzles are normally used to produce icing clouds with MVD of 14 to $40 \mu \mathrm{m}$ using air pressures from 10 to $80 \mathrm{psig}$.

\section{Model}

The test article was a 77.25 inch chord Twin Otter wing section with a $30 \%$ chord flap. The leading edge of the model was outfitted with a full-span pneumatic de-icer boot extending to $10 \%$ chord on the suction surface, and to $11 \%$ chord on the pressure surface. A picture of the test article is shown in Figure 3.

The model was also instrumented with 16 Type-T thermocouples at a spanwise location of 42 inches above the tunnel floor. The thermocouples were located at various chordwise positions, both on the 
boot and on the metal skin of the airfoil as shown in Figure 4. A very thin patch of boot material (.01 inch) was used to cover the boot thermocouples, providing physical protection and also providing a good boot surface temperature measurement.

\section{LARGE DROPLET SPRAY CALIBRATION}

The calibration of the IRT's icing cloud was extended to include the large droplet sizes chosen for this investigation $(99 \mu \mathrm{m}$ and $160 \mu \mathrm{m})$. The LWC was fixed at a single value for each of the above droplet sizes. No further calibration was required for the $40 \mu \mathrm{m}$ droplets, since these droplets are within the standard IRT cloud calibration envelope.

\section{Determination of Liquid Water Content}

To determine the liquid water content (LWC), nine 1.5 inch diameter vertical cylinders spaced at nine inches were mounted in the test section of the tunnel. The cylinders were rotated at approximately $60 \mathrm{rpm}$. They were exposed to the icing cloud for a predetermined length of time. The resulting ice accretion was determined by measuring the diameter of the iced cylinders using a probe which traversed each cylinder from 6 inches above the tunnel floor to 10 inches from the tunnel ceiling. The data recorded was the iced diameter measurement at vertical intervals of 1.25 inches for each cylinder.

The recorded data was used to plot the LWC uniformity in the test section and to calculate the central value of LWC. The central LWC value was calculated using the equation:

$$
L W C=\frac{C^{*} \Delta r}{E_{b}{ }^{*} V^{*} t / 2}
$$

where:

$$
\begin{aligned}
& \Delta r \text { is the ice thickness on the cylinder at the } \\
& \text { center location } \\
& E_{b} \text { is the average collection efficiency } \\
& V \text { is the airspeed } \\
& t \text { is time } \\
& C \text { is a constant which includes the ice density }
\end{aligned}
$$

The ice density is assumed to be 0.88 . Using the units of $\Delta r$ in inches, $V$ in miles per hour and $t$ in seconds, the value of $C$ is $5.0 \times 10^{4}$. The time is divided by 2 since one half of the cylinder is always exposed to the cloud impingement.
Determination of Droplet Size

Droplet size distributions were measured in the center of the tunnel test section using two laser-based instruments. A forward scattering spectrometer probe, model FSSP100 , was used to measure droplets with diameters between 2 and $47 \mu \mathrm{m}$ and an optical array probe, model OAP230X, was used to measure droplets with diameters from 47 to $450 \mu \mathrm{m}$. Both of these instruments are manufactured by Particle Measuring Systems Inc. in Boulder, Colorado.

Each probe was alternately placed in the center of the tunnel and the stabilized icing cloud was sampled for 100 seconds at an airspeed of $195 \mathrm{mph}$. For these tests only every other spraybar was operated to reduce the droplet number densities to acceptable levels for the FSSP to make valid measurements. Reference I details the comparison of using all spraybars and half-spraybars on the FSSP results and the rationale for why half-spray results are more acceptable.

The standard PMS data correction algorithms were used including an "activity" correction for the FSSP and bin depth of field and effective array with corrections for the OAP. The droplet distributions from each probe were combined and the median volumetric diameter (MVD) was calculated The LWC was also computed from the combined droplet distribution as a check against the rotating cylinder LWC.

As an alternate to the PMS data correction algorithm, the NCAR (Baumgardner) methodology was used to determine the effect it would have on the calculated MVD and LWC ${ }^{2}$ A comparison of the calculated values of MVD and LWC resulting from the PMS and NCAR methods is shown in Table 1 and the number density and LWC distributions are shown in Figure 5. For both spray conditions, the NCAR method resulted in a decrease of 23 to 30 percent in the MVD and an increase of 330 to 389 percent in the LWC. The LWC values resulting from the PMS corroction algorithm were judged to be more reasonable since they agreed much more closely with the rotating cylinder values. As can be seen in Figure 5 , the droplet distributions generated with the OAP/PMS correction algorithm are smoother and exhibits a better match to the FSSP distributions than the OAP/NCAR correction algorithm. Therefore the MVD values calculated with the PMS algorithm were used as the representative values for these spray conditions.

\section{DROPLET SUPERCOOLING INVESTIGATION}

When the IRT is used to produce icing clouds with normal cloud droplet sizes of 14 to $40 \mu \mathrm{m}$, droplet 
supercooling is accelerated by the expansion and subsequent cooling of the pressurized air used in the nozzles to promote droplet breakup. The air and water are normally heated to approximately $175^{\circ} \mathrm{F}$ to preclude droplet frecze-out. Low atomizing air pressures of 2 to 5 psig were used to generate large droplets, thereby significantly reducing expansion cooling. Since large droplets contain a larger amount of mass to cool, the loss of expansion cooling raised concerns that the droplets might not reach ambient temperature before impinging on the model.

A computer code developed by the Arnold Engineering Development Center (AEDC) was used to determine the effect of spraybar water temperature on the degree of droplet cooling. ${ }^{3}$ Table 2 shows the predicted final droplet temperature for initial water temperatures of 50,100 , and $200{ }^{\circ} \mathrm{F}$. For all code runs, the tunnel test section airspeed was $195 \mathrm{mph}$, the tunnel total temperature was $28{ }^{\circ} \mathrm{F}$, and the initial relative humidity at the spray location was $83 \%$. $T_{d}$ $T_{a}$ represents the difference between the droplet teraperature and the air temperature.

It can be seen from Table 2 , that the initial water temperature had a negligible effect on the final droplet temperature. Varying the initial water temperature from $50^{\circ} \mathrm{F}$ to $200^{\circ} \mathrm{F}$ resulted in only a $0.1^{\circ} \mathrm{F}$ change in droplet temperature. Also, the maximum temperature difference (between the droplets and the air) was predicted to occur for the largest droplet size of $160 \mu \mathrm{m}$, where the droplets were predicted to be 1.8 ${ }^{\circ} \mathrm{F}$ warmer than the air.

An experiment was conducted to examine the validity of the code results for icing spray clouds with MVD's of $99 \mu \mathrm{m}$ and $160 \mu \mathrm{m}$. Experimental icing runs were conducted in the IRT at an airspeed of $195 \mathrm{mph}$ and a total temperature of $28^{\circ} \mathrm{F}$. A temperature of $28^{\circ} \mathrm{F}$ was suitable for this investigation because it was near freezing, yet didn't exhibit appreciable water runback and random ice shedding. The result was a traceable ice shape. For each droplet size, the atomizing air and water temperatures were varied between nominal values of $50^{\circ} \mathrm{F}, 100^{\circ} \mathrm{F}$, and $200^{\circ} \mathrm{F}$. Ice was accreted on the model, and ice shape tracings were obtained. These ice shape tracings were then compared to determine how the initial spray and water temperature affected the resultant ice accretion. It should be mentioned that nominal spraybar temperature values were not always achieved. An attempt was made to get as close as possible to the nominal values for those cases.
Figure 6 presents experimental ice shape tracings resulting from 3 different initial spraybar air and water temperatures and a $160 \mu \mathrm{m}$ MVD icing cloud. A comparison of the thre ice tracings reveals that the ice shapes are virtually identical for this range of spraybar air and water temperatures. This experimental result confirms the AEDC code predictions and lends credibility to the code predictions that the droplets are supercooled (with a temperature close to that of the airstream).

Figure 7 provides additional experimental evidence which appears to support the above conclusion. Figure 7 is a time-history plot of temperature obtained from a leading-edge thermocouple. Temperature measurements are plotted for the first 75 seconds of a $160 \mu \mathrm{m}$ MVD icing spray. The icing spray was initiated at $\mathrm{t}=0$ seconds. Initially, the leading-edge was near the tunnel total temperature of $28{ }^{\circ} \mathrm{F}$. Visual observation of this leading-edge region indicated that the icing cloud first impinged on the model at 9 seconds. Note that at this time the leading-edge temperature began to dip. Over the next 5 seconds the temperature continued to decrease to a minimum of $1.5^{\circ} \mathrm{F}$ below the initial value. At $\mathrm{t}=21$ seconds complete freezing of the leading edge area was observed, which is where the temperature profile of Figure 7 began leveling at $32^{\circ} \mathrm{F}$.

The temperature profile shown in Figure 7 suggests that the impinging droplets were initially cooling the airfoil surface below the total temperature of the tunnel (approximately $28.5^{\circ} \mathrm{F}$ ). To cool the leadingedge by $1.5^{\circ} \mathrm{F}$, the droplet temperature would have to have been no greater than $27^{\circ} \mathrm{F}$. It was likely that the droplet temperature was actually between the airstream static temperature of $21.7^{\circ} \mathrm{F}$ and $27^{\circ} \mathrm{F}$. Note that the AEDC code predicted that the $160 \mu \mathrm{m}$ droplets would be $1.9^{\circ} \mathrm{F}$ above the airstream static temperature (see Table 2); thus by this prediction, the droplet temperature would be approximately $23.6^{\circ} \mathrm{F}$.

Clearly, the AEDC analysis and experimental observations lead to the conclusion that the large droplets produced in the IRT are supercooled and approach the static temperature of the airstream.

\section{PARAMETRIC INVESTIGATION}

The objective of this portion of the test program was to study how parameters such as temperature, droplet size, AOA, airspeed, flap setting, and de-icer boot 
cycle times affect large droplet ice accretions. Additionally, it was desired to compile a database of large droplet ice accretions which could be used to better characterize this phenomena. Table 3 lists the range of parameter values which were evaluated for their effect on large droplet ice accretions. A test matrix was developed using the parameter values defined in Table 3 and subsequently used to guide the testing in the IRT.

The test matrix was developed with the assumption that both droplet size and near-freezing temperatures are key parameters affecting large droplet ice accretions. Therefore, a temperature "sweep" was incorporated into the matrix to investigate large droplet ice accretions at temperatures within $+/-4^{\circ} \mathrm{F}$ of the freezing point. Previous large droplet studies conducted in the IRT suggested that nunback and ice sliding may be important features of ice accretions at near-freezing temperatures, as these characteristics had been observed at temperatures at or above $28{ }^{\circ} \mathrm{F}$. Therefore, $28{ }^{\circ} \mathrm{F}$ was chosen as the lower temperature bound for the temperature sweep.

It was not possible to test all of the conditions reflected in Table 3 within the tunnel time alotted for this test program. Therefore, as the temperature sweep was conducted, one temperature was selected as an "anchor-point". This temperature remained fixed, while the other parameters of interest were varied (hence the name "anchor-point"). The selection of the "anchor point" was subjective and based on consultation with NASA colleagues who had conducted previous large droplet investigations in the IRT. Ice accretions obtained at the anchor point temperature were believed to be most representative of the large droplet icing condition. The "anchor-points" selected for this investigation were $T_{t}=30$ o $F$ at airspeeds of $125 \mathrm{mph}$ and $163 \mathrm{mph}$, and $\mathrm{T}_{\mathrm{t}}=32{ }^{\circ} \mathrm{F}$ at an airspeed of $195 \mathrm{mph}$.

In addition to the temperature sweep, large droplet ice accretions were studied at two other temperatures: $5^{\circ} \mathrm{F}$ and $0^{\circ} \mathrm{F}$. The $5^{\circ} \mathrm{F}$ condition was chosen based on meteorological evidence suggesting that the large droplet condition may extend as low as $5{ }^{\circ} \mathrm{F}$, while the 0 F condition was chosen to obtain impingement information with short duration icing sprays. ${ }^{4}$

The droplet sizes selected for this investigation ranged from the upper end of the standard IRT icing cloud envelope to near the limit of what is currently attainable with the existing IRT spray bar system. It was found that as the droplet MVD was increased, the LWC of the icing cloud became more nonuniform over the area of the test section. After review of the large droplet spray calibration data, it was decided that the $160 \mu \mathrm{m}$ MVD cloud: 1) provided an acceptable area of uniform LWC at the center of the test section and 2) provided the largest droplet size distribution which could be confidently measured with the available droplet size measuring instrumentation.

The lower limit airspeed of $125 \mathrm{mph}$ represents a typical approach condition for the Twin Otter aircraft, while the upper airspeed limit of $195 \mathrm{mph}$ was chosen to provide enough of an airspeed variation that its effect on the large droplet ice accretions could be studied.

The four angles of attack and the three flap settings were considered to be typical of nominal Twin Otter flight conditions. Also, because this was a rather large chord model (77.25"), it was decided to limit the angle-of-attack to minimize tunnel blockage effects.

Four different de-icer boot cycling times were tested, which ranged from no activation of the boot to cycling the boot in 6 minute intervals. A 3 minute boot cycle time was the normal cycling interval, while the $.7 \mathrm{~min}$ cycling time represented the fast cycling interval for the Twin Otter.

\section{Ice Shape Repeatability}

Since the effect of large droplet ice accretion on the aerodynamic performance of an aircraft is due to the peculiar way it accumulates, the ice shape that forms is of key importance in studying these effects. Therefore, a significant part of this study was to record large droplet ice accretions under various conditions such as: temperature, airspeed, droplet size, model angle-ofattack, model flap setting, and de-icer boot cycling time. Underlying this type of study is the question of how well an ice shape is reproduced under a given set of these parameters.

There are two aspects to the question of repeatability in this study. The first concerns the ability to closely reproduce icing conditions in the IRT. The second centers around how well an ice shape reproduces itself in a given set of conditions. This latter aspect may at first appear to be totally dependent upon the first. However, in these tests, the ice protection system did not completely remove the accumulated ice and the shape of the residual ice was always somewhat random. Furthermore, at total temperatures very near 
freezing $\left(32+/-2^{\circ} \mathrm{F}\right)$, the accumulated ice would often be shed off the model independent of the ice protection system activation. This "self-shedding" occurred in a random manner, leaving behind a variable ice shape.

As has been found in previous studies, the ability to reproduce icing conditions in the IRT is very good and continues to improve as enhancements are continually being made to the tunnel. ${ }^{5}$ Moreover, results found during the droplet cooling portion of this study also indicated that the IRT reproduces icing conditions very well.

Variation in ice shapes formed under nearly identical conditions can be seen in Figures 8 and 9. Figure 8 shows ice shape tracings from the spanwise centerline of the airfoil for three separate test runs at the same set of conditions. The active portion of the ice protection system extends to approximately $7.5 \%$ chord on the suction surface. It can be seen that the ridge of residual ice forms in the general vicinity of the edge of the active portion of the boot. However, the ridge varies considerably in height and shape as well as in location from $7 \%$ to $9.5 \%$ chord. Similar results can be seen in Figure 9, which shows three nearly identical cloud runs at a total temperature of $31^{\circ} \mathrm{F}$, rather than at $32^{\circ} \mathrm{F}$.

This random variation in ridge location, height and shape was found throughout this entire series of tests. This characteristic of near-freezing temperature large droplet ice accretion could well be a cause of the unpredictability of it's effect on aircraft performance.

\section{Total Temperature Effect}

The effect of total temperature on large droplet ice accretions was investigated by varying the total temperature from $36^{\circ} \mathrm{F}$ down to $5^{\circ} \mathrm{F}$, and then comparing the features of the resultant ice accretions. This was done at the following nominal condition: MVD $=160 \mu \mathrm{m}, A O A=0^{\circ}$, Flap $=0^{\circ}$, Boot cycle $=3$ min, Spray $=18$ minutes, and $V=125$ and $195 \mathrm{mph}$. Generally speaking, the trends noted at $195 \mathrm{mph}$ were similar to those observed at $125 \mathrm{mph}$. The only difference was in the temperature at which trends were observed to begin or end.

At $T_{t}=36^{\circ} \mathrm{F}$, all the impinging water ran back to the trailing-edge and was blown off the model. Decreasing the temperature to $34^{\circ} \mathrm{F}$, less runback was noted and an ice accretion formed at $\mathrm{V}=195 \mathrm{mph}$. The temperature had to be decreased to $32{ }^{\circ} \mathrm{F}$ before an accretion was observed at $125 \mathrm{mph}$. When the ice accretion began to form, there was a distinct ridge noted aft of the active portion of the de-icer boot on both the suction and pressure surfaces.

As the temperature was decreased still further, less and less runback was observed aft of the boot probably because more of the water was freezing earlier during the runback process. Eventually, a temperature was reached where the ice ridge on the boot (aft of the active portion) appeared to reach a relative maximum. This temperature was $30^{\circ} \mathrm{F}$ for $\mathrm{V}=195 \mathrm{mph}$, while at $125 \mathrm{mph}$ this temperature was $28{ }^{\circ} \mathrm{F}$.

The pictures in Figure 10 visually depict what a strong effect the total temperature has on the large droplet ice accretion. The lines on the model indicate 5, 10, and $15 \%$ chord locations. Figure 10a shows the ice accretion on the suction surface for a total temperature of $32{ }^{\circ} \mathrm{F}$. Runback extended from just aft of the deicer boot at $10 \%$ chord to beyond $15 \%$ chord. Note the lack of a defined ridge just aft of the active portion of the boot at $7.5 \%$ chord. Any ice ridge that formed tended to be very "slushy" and subsequently was blown off the airfoil at this temperature.

Dropping the total temperature to $30^{\circ} \mathrm{F}$ resulted in the accretion shown in Figure 10b. There was much less runback aft of the boot, and a thin layer of glaze ice was visible between $7.5 \%$ to $10 \%$ chord. However, the ice was "wet" and lacked adhesive strength, because the upper portion of the ridge was shed. Also, we see the beginning of ice protuberances or nodules just aft of $10 \%$ chord. These nodules grew normal to the surface and were consistently found just aft of an ice ridge.

When the total temperature was further decreased to $28{ }^{\circ} \mathrm{F}$, we saw a marked change in the ice accretion. Now the ridge appeared to have more structural strength and, in this case, had resisted shedding. Also note the lack of runback and the very well defined nodule growth aft of the de-icer boot. It is very evident from this sequence of pictures in Figure 10, that small changes in total temperature can have a very significant effect on the resultant large droplet ice accretion when the total temperature is near $32{ }^{\circ} \mathrm{F}$.

It was also noted that a liquid region existed at the leading-edge of the airfoil. The width of this zone was observed to directly correlate with total temperature. The warmer the temperature, the wider this zone was. Boot thermocouple temperature data verified this observation. Table 4 compares leading-edge boot 
thermocouple temperatures obtained at total temperatures of $28{ }^{\circ} \mathrm{F}$ and $0{ }^{\circ} \mathrm{F}$. Almost all of the leading-edge thermocouples have temperatures near $32{ }^{\circ} \mathrm{F}$ for $\mathrm{T}_{t}=28{ }^{\circ} \mathrm{F}$, while only one thermocouple has a temperature near $32^{\circ} \mathrm{F}$ for $\mathrm{T}_{\mathrm{t}}=0^{\circ} \mathrm{F}$.

\section{Droplet Size Effect}

When considering how to evaluate the effect of droplet size on large droplet ice accretions at near freezing temperatures, it was recognized that both impingement and runback contribute to the formation of the resultant ice accretion. Therefore, testing was conducted at $0{ }^{\circ} \mathrm{F}$ to characterize impingement characteristics with 40,99 , and $160 \mu \mathrm{m}$ MVD droplets. Then similar test runs were repeated at near freezing temperatures to characterize runback effects.

Droplet Impingement at $0{ }^{\circ} \mathrm{F}$ : Much of the testing for this investigation was done over a period of eighteen minutes in order to include a number of cycles of pneumatic boot operation. This procedure allowed the fullest examination of the peculiarities of large droplet ice accretion. However, to establish airfoil impingement limits shorter spray times were used for some tests. Shorter spray times were needed because ice buildup changes the airflow around the leadingedge thereby affecting the droplet impingement. Low temperatures were also needed to ensure freezing on impact such that nunback was prevented.

To document the initial large droplet impingement limits on the Twin Otter airfoil, a number of short duration sprays were carried out at a total temperature of $0^{\circ} \mathrm{F}$ at various droplet sizes, airspeeds, and airfoil angles-of-attack. The results of these test rums are given in Table 5, along with LEWICE impingement limit predictions. In general, as the droplet size increased, the impingement limits also increased for a given airspeed and AOA. When the AOA was varied with the airspeed and droplet size held constant, the impingement limits shifted significantly. As the airfoil was rotated from a positive to a negative $A O A$, the impingement limit on the suction surface moved aft, while the impingement limit on the pressure surface moved fore. Finally, a change in airspeed while holding droplet size and AOA constant was observed to have no effect on the impingement limits.

In addition to these tests, one other set of impingement tests was conducted. As mentioned earlier, a buildup of ice on an airfoil can alter the droplet impingement limits. When a ridge of ice is formed aft of the ice protection system, the airflow is obviously altered. It was, therefore, of interest to determine what effect this had on the impingement limits. To accomplish this, the airfoil was subjected to a large droplet icing cloud at near freezing temperature for eighteen minutes while cycling the ice protection system at three minute intervals. The icing spray was then turned off and the tunnel air temperature was reduced to $0^{\circ} \mathrm{F}$. The icing spray was again turned on; this time for only a short period of one minute. The ice from the two sprays could be distinguished by its type. The ice formed at near freezing was predominately glaze ice, while that formed at well below freezing was rime ice. The rime ice collected on the pneumatic boot and on the ice ridge just aft of the boot. No rime ice was observed on the airfoil or on the glaze ice which had formed aft of the ridge. This strongly suggests that the ice which had formed aft of the ridge on the airfoil was not from direct impingement. It was either from runback along the surface of the airfoil or from liquid droplets which had collected on the ice ridge and then been blown off the ridge onto the airfoil fiurther downstream.

Flow visualization using a sheet laser clearly indicated the presence of a separation bubble immediately downstream of the ridge in which such droplets could have been entrained and redirected toward the airfoil. The ice formed on this area of the airfoil in these conditions was not of conventional glaze, rime, or mixed types. Rather it was an area of individual ice "nodules" or protuberences which grew normal to the surface of the airfoil. The shape of these nodules was peculiar as well; having a flat surface facing downsteam with a semi-hemispherical surface facing upstream and attached to the surface by a thin stem. In addition, the radius of the semi-hemisphere grew larger as the nodule grew away from the surface of the airfoil. These nodules were observed to grow as much as an inch away from the surface. Under some conditions, the nodules actually grew together into a large mass of ice. Figure 11 shows a sketch of a typical nodule.

Droplet Size Effect at Near $32^{\circ} \mathrm{F}$ : Also of interest in this investigation was the documentation of variation in ice accretion due to changing droplet size at near freezing temperatures. Unfortunately, the MVD and LWC could not be set independently at the larger drop sizes. A change in MVD resulted in a corresponding change in LWC. Thus it was not possible to investigate the effect of droplet size at a constant LWC. 
In general, as the median droplet size increased, the ice could be seen to accumulate further and further aft on both the suction and pressure surfaces of the airfoil. Figure 12 shows ice shapes formed from each of the three median droplet sizes. As seen in the figure, the extent of the ice accretion on the suction surface increased from about $7 \%$ chord for $40 \mu \mathrm{m}$ MVD droplets to $10 \%$ chord for $99 \mu \mathrm{m} \mathrm{MVD}$ droplets to $15 \%$ chord for $160 \mu \mathrm{m}$ MVD droplets. Again, it is worthy to note that the active portion of the boot ended at $7.5 \%$ chord on the suction surface.

\section{Angle-of-Attack Effect}

As the angle of attack of the airfoil was changed, the droplet impingement and the ice accretion were expected to change as well. Tests were run with the model set at AOA's of $-2,0,2$, and 4 degrees to investigate this effect. Ice shapes obtained at various AOA are shown in Figure 13 for airspeeds of $125 \mathrm{mph}$ and $195 \mathrm{mph}$. Generally speaking, an increase in AOA caused more ice to accrete on the pressure surface, while a decrease in AOA caused more ice to accrete on the suction surface.

As expected, at $-2^{\circ}$ AOA the ice accretion extended further aft over the suction surface than in the other $\mathrm{AOA}$ cases. At $+4 \mathrm{AOA}$, ice accumulated along the entire length of the pressure surface of the model.

Table 6 shows the maximum and minimum ridge heights at various AOA's. Ridge heights were measured at three spanwise locations (at model centerline, and at -5 inches and +4 inches on each side of the centerline) on both the suction and pressure surfaces of the airfoil. The maximum and minimum from these three measurements are listed in the table for both surfaces.

\section{Effect of Flap Setting}

Several tests were run at various flap settings to investigate the effect this parameter has on large droplet ice accretion. Most of the tests were run with the flap stowed (i.e.- at a setting of $0^{\circ}$ ). The two alternate flap settings were at $10^{\circ}$ and $20^{\circ}$. On the Twin Otter aircraft for a given flap setting, the actual flap deflection varies across the span of the flap on the wing. Since this model is a six foot section just inboard of the aileron, the actual flap deflection was approximately $8^{\circ}$ for the $10^{\circ}$ setting and approximately $16^{\circ}$ for the $20^{\circ}$ setting. All tests run at flap settings of $10^{\circ}$ and $20^{\circ}$ were at an airspeed of 125 mph as Twin Otter airspeed is limited with flaps deployed.
At an AOA of $0^{\circ}$, little effect on ridge formation could be discerned on either the suction or pressure surface as a result of a flap setting change. However, changing the flap setting did affect the extent of ice accretion aft of the ridge on the suction surface. For all cases tested, as the flap setting increased, the extent of ice accretion on the suction surface (in terms of chordwise coverage) decreased appreciably. There was a decrease from $16 \%$ chord at flaps $0^{\circ}$, to $12.5 \%$ chord at flaps $10^{\circ}$, to about $9 \%$ chord at flaps $20^{\circ}$. This change in icing extent is shown in the ice accretions of Figure 14.

The extent of ice accretion on the pressure surface was about the same for flaps $0^{\circ}$ and flaps $10^{\circ}$. At flaps $20^{\circ}$, ice did accumulate further aft on the pressure surface than at the other two flap settings and a significant amount of ice did accumulate on the pressure surface of the flaps at this setting. Table 7 lists some of the measured ridge heights obtained with various flap settings at $0^{\circ} \mathrm{AOA}$.

At an AOA of $-2^{\circ}$ with the flaps set at $20^{\circ}$, ice accumulated further aft on the suction surface than in the $0^{\circ}$ AOA case $(12.5 \%$ chord compared to $9 \%$ chord). The extent of ice accretion on the pressure surface was less than in the $0^{\circ} \mathrm{AOA}$ case.

\section{Effect of Boot Cycle}

On the Twin Otter, the pilot has the choice of two different time periods between activation of the pneumatic ice protection boot, approximately 45 seconds and three minutes. Most of the testing conducted in this study was done using a three minute boot cycle time. However, several tests were conducted at other boot cycle times to investigate this effect. The alternate boot cycle times used were 42 seconds, six minutes, and no boot cycling whatsoever. The spray times for all of these runs was eighteen minutes.

For the near freezing cases nun with no boot cycling, ice would accumulate on the leading edge to some point, then be blown off. A significant but irregular ridge would always remain in the area of $7.8 \%$ chord on the suction surface. It was irregular in the sense that random spanwise portions of it could also be blown off, leaving discontinuous spanwise lengths of ridge.

Using a boot cycle time of six minutes, the resulting ice accumulations looked similar to that of the no boot cycle condition although, overall, there appeared to be 
slightly less ice accretion. Again, the discontinuous ridge formed. Similar trends were seen for the three minute and $\mathbf{4 2}$ second boot cycle times as slightly less ice accretion was observed but each with a discontinuous ridge.

\section{SUMMARY OF RESULTS}

A study of large droplet ice accretions at near freezing temperatures was conducted in the IRT using a fullscale Twin Otter wing section. Following calibration of the IRT icing cloud for large droplet sizes of $99 \mu \mathrm{m}$ and $160 \mu \mathrm{m}$ MVD, a droplet cooling study was conducted. Results from this study, indicated that:

- Varying the initial spraybar water temperature had no discernible effect on the resultant large drop ice accretion.

- Leading-edge thermocouples indicated that the large droplet spray cooled the airfoil leadingedge as it impinged at the start of an icing spray. This result suggested that droplets were at a temperature below the total temperature of the airstream.

A parametric study was also conducted to determine the effect of various parameters on large drop ice accretions. Results from this study indicated that:

- An ice ridge formed after the active portion of the de-icer boot for almost every experimental run. The exact location of the ridge varied slightly along with it's height and spanwise extent. This variability was caused by random aerodynamic shedding of the ice ridge.

- Large drop ice accretions were found to be very sensitive to changes in total temperature, and as the temperature was varied, the ice ridge appeared to reach a relative maximum at $T_{t}=28$ of $(125 \mathrm{mph})$, and $T_{t}=30$ \% $(195 \mathrm{mph})$.

- An increase in droplet size moved the impingement limits farther aft on the airfoil, while a decrease in droplet size moved the impingement limits forward. The additional effect of runback and secondary impingement accreted ice even further aft on the airfoil.

- Increasing the AOA caused more ice to accumulate on the pressure surface and less ice on the suction surface. Decreasing the $A O A$ resulted in more ice accreting on the suction surface and less on the pressure surface.
- As flap setting was increased, the extent and amount of ice accretion on the suction surface decreased. The ice accretion on the pressure surface was noticeably affected only for a flap setting of $20^{\circ}$ where ice accreted over the entire length of the pressure surface (including the flap).

- Variation in the boot cycling time did not appear to have a clearly defined effect on the resultant ice accretion. An ice ridge always formed aft of the active portion of the de-icer boot, regardless of boot cycling time.

\section{CONCLUDING REMARKS}

The droplet cooling study provided strong evidence, supported by analytical results, that even $160 \mu \mathrm{m}$ droplets are supercooled in the $\mathrm{IRT}$ test section.

One of the primary results which emerged from the large droplet testing at near freezing temperatures, concerned the variability of the ice ridge aft of the active portion of the de-icer boot. This variability inherently makes it more difficult to repeat the same test condition, and obtain the same ice shape. Therefore, it is important to recognize that repeatability is a significant issue associated with large droplet icing tests conducted at near freezing conditions.

Results from the parametric investigation presented in this paper were obtained with a Twin Otter wing section. It is recognized that somewhat different results might have been obtained with a different airfoil. Therefore, additional testing has been planned with other airfoil sections to isolate "airfoil-specific" effects.

\section{ACKNOWLEDGEMENTS}

This paper represents the cumulative efforts of many individuals at NASA-Lewis Research Center, and would not have been possible without their contributions. The authors would like to acknowledge: - Members of the Icing Technology Branch for providing technical counsel, analytical support, and their help in the development and implementation of this test program

- The IRT technical crew for their assistance with the test article installation \& checkout, and also for all facets of tunnel operation,

- Mr. David Sheldon, who provided engineering support and oversight, and for his expertise in the installation of temperature instrumentation 
- Ms. Tammy Langhals for the digitization of ice shape tracings, and her expertise in the preparation of figures for this report

- Ms. June Thompson, and Mr. Charles Andracchio for their role in programming and configuring the data acquisition system

- Mr. Vic Cannacci for setup and operation of the sheet laser for flow visualization studies

- Technical Imaging specialists for their assistance with still, time lapse, and video photography

The authors would also like to express their appreciation to the B.F. Goodrich Company for installing the de-icer boot and the leading-edge thermocouples.

\section{REFERENCES}

1. Performance of the Forward Scattering Spectrometer Probe in NASA's Icing Research Tunnel, Hovenac, E., and Ide, R, NASA TM101381, AIAA89-0769.

2. Baumgardner, D., Corrections for the response time of particle measuring probes. Reprints of the 6th Symposium on Meteorological Observation and Instrumentation, New Orleans, January 12-16, 1987, pp. 148-151.

3. Wilbanks, C., and Schulz, R, Analytical Study of Icing Simulation for Turbine Engines in Altitude Test Cells, AEDC-TR-73-144, November 1973.

4. Jeck, R, Representative Values of Icing Related Variables Aloft in Freezing Rain and Freezing Drizzle, FAA Tech Note DOT/FAA/AR-TN95/119.

5. Shin, J. and Bond T. H., "Repeatability of Ice Shapes in the NASA Lewis Icing Research Tunnel," Journal of Aircraft, Vol 31, No. 5, pp. 1057-1063, Sept-Oct, 1994. 
Table 1. Comparison of PMS and NCAR correction algorithms for two large droplet spray conditions

\begin{tabular}{|c|c|c|c|c|c|c|}
\hline $\begin{array}{c}\text { Spray } \\
\text { Air } \\
\begin{array}{c}\text { Pressure } \\
\text { (psig) }\end{array}\end{array}$ & $\begin{array}{c}\text { Spray Water } \\
\text { Pressure } \\
(\mathrm{psig})\end{array}$ & $\begin{array}{c}\text { Rotating } \\
\text { Cylinder } \\
\text { LWC } \\
\left(\mathrm{g} / \mathrm{m}^{3}\right)\end{array}$ & $\begin{array}{c}\text { PWC } \\
\left(\mathrm{g} / \mathrm{m}^{3}\right)\end{array}$ & $\begin{array}{c}\text { MVD } \\
(\mu \mathrm{m})\end{array}$ & $\begin{array}{c}\text { NCAR } \\
\left(\mathrm{g} / \mathrm{m}^{3}\right)\end{array}$ & $\begin{array}{c}\text { NVD } \\
(\mu \mathrm{m})\end{array}$ \\
\hline 6 & 36 & 0.54 & 0.57 & 98.7 & 2.94 & 75.6 \\
\hline 5 & 55 & 0.82 & 0.94 & 160.7 & 3.10 & 111.7 \\
\hline
\end{tabular}

Table 2. AEDC Code (ref 3) prediction of effect of initial spray water temperature on final droplet temperature $\left(\mathrm{T}_{\mathrm{t}}=28^{\circ} \mathrm{F}, \mathrm{T}_{\mathrm{a}}=21^{\circ} \mathrm{F}, \mathrm{V}=195 \mathrm{mph}\right)$

\begin{tabular}{|c|c|c|}
\hline $\begin{array}{c}\text { Water } \\
\text { Temperature } \\
\left({ }^{\circ} \mathrm{F}\right)\end{array}$ & $\begin{array}{c}\text { Droplet Size } \\
(\mu \mathrm{m})\end{array}$ & $\begin{array}{c}\text { Temperature } \\
\text { Difference } \\
\mathrm{T}_{\mathrm{d}}-\mathrm{T}_{\mathrm{s}} \\
\left({ }^{\circ} \mathrm{F}\right)\end{array}$ \\
\hline 50 & 40 & 0.6 \\
\hline & 99 & 1.0 \\
\hline & 160 & 1.8 \\
\hline 100 & 40 & 0.5 \\
\hline & 99 & 1.1 \\
\hline & 160 & 1.8 \\
\hline 200 & 40 & 0.6 \\
\hline & 99 & 1.1 \\
\hline & 160 & 1.9 \\
\hline
\end{tabular}

Table 3. Range of parameter values for large droplet parametric study

\begin{tabular}{|l|l|}
\hline Total Temperature $\left({ }^{\circ} \mathrm{F}\right)$ & $0,5,28,30,32,34,36$ \\
\hline Droplet Size $(\mu \mathrm{m})$ & $40,99,160$ \\
\hline Airspeed (mph) & $125,163,195$ \\
\hline Angle-Of-Attack $(\mathrm{deg})$ & $-2,0,2,4$ \\
\hline Flap Setting (deg) & $0,10,20$ \\
\hline Boot Cycle (minutes) & none, $, 7,3,6$ \\
\hline
\end{tabular}

Table 4. Leading-edge temperature profile measured 75 seconds after start of icing spray at $0^{\circ} \mathrm{F}$ and $28^{\circ} \mathrm{F}$

\begin{tabular}{|c|c|c|c|c|c|c|c|c|c|}
\hline & \multicolumn{7}{|c|}{ Measured Boot Thermocouple Temperatures } \\
\hline $\begin{array}{c}\mathrm{T}_{\mathbf{t}} \\
\left({ }^{\circ} \mathrm{F}\right)\end{array}$ & $\mathrm{TC1})$ & $\mathrm{TC} 2$ & $\mathrm{TC} 3$ & $\mathrm{TC4}$ & $\mathrm{TC5}$ & $\mathrm{TC6}$ & $\mathrm{TC7}$ & $\mathrm{TC8}$ & $\mathrm{TC} 9$ \\
\hline 28 & 26.5 & 30.5 & 31.8 & 31.5 & 32.0 & 31.9 & 31.5 & 31.4 & 27.5 \\
\hline 0 & 3.0 & 9.5 & 14.0 & 25.5 & 30.5 & 24.5 & 15.5 & 11.5 & 4.5 \\
\hline
\end{tabular}


Table 5. Effect of droplet MVD, airspeed, and AOA on observed impingement limits $\left(\mathrm{T}_{\mathrm{t}}=30^{\circ} \mathrm{F} @ \mathrm{~V}=125,163 \mathrm{mph}, \mathrm{T}_{\mathrm{t}}=32^{\circ} \mathrm{F} @ \mathrm{~V}=195 \mathrm{mph}\right.$, Flap=0 $0^{\circ}$, Boot Cycle $\left.=3 \mathrm{~min}\right)$

\begin{tabular}{|c|c|c|c|c|c|c|c|c|}
\hline \multirow[t]{2}{*}{$\begin{array}{l}\text { Parameter } \\
\text { Varied }\end{array}$} & \multirow[t]{2}{*}{$\begin{array}{c}\text { Run } \\
\text { Number }\end{array}$} & \multirow{2}{*}{$\begin{array}{l}\text { Icing } \\
\text { Cloud } \\
\text { MVD } \\
(\mu \mathrm{m})\end{array}$} & \multirow[t]{2}{*}{$\begin{array}{c}\text { Airspeed } \\
\text { (mph) }\end{array}$} & \multirow{2}{*}{$\begin{array}{l}\text { Angle- } \\
\text { of-Attack } \\
\text { (deg) }\end{array}$} & \multicolumn{2}{|c|}{$\begin{array}{l}\text { Suction Surface Limit } \\
(\% \text { chord })\end{array}$} & \multicolumn{2}{|c|}{$\begin{array}{c}\text { Pressure Surface Limit } \\
\text { (\% chord) }\end{array}$} \\
\hline & & & & & $\begin{array}{l}\text { meas } \\
(\text { IRT) }\end{array}$ & $\begin{array}{c}\text { calc } \\
\text { (LEWICE) }\end{array}$ & $\begin{array}{l}\text { meas } \\
\text { (IRT) }\end{array}$ & $\begin{array}{c}\text { calc } \\
(L E W I C E)\end{array}$ \\
\hline \multicolumn{9}{|l|}{ droplet size } \\
\hline & 13 & 40 & 125 & 0 & 7.5 & 4.8 & 7.5 & 2.7 \\
\hline & 14 & 99 & 6 & $"$ & 8.5 & 10.0 & 10 & 8.8 \\
\hline & 12 & 160 & $"$ & $"$ & 13 & 16.0 & 11 & 12.5 \\
\hline \multicolumn{9}{|l|}{ droplet size } \\
\hline & 53 & 40 & 195 & 0 & 7 & 4.8 & 8 & 3.5 \\
\hline & 54 & 99 & $"$ & $"$ & 9 & 11.0 & 10 & 8.8 \\
\hline & 52 & 160 & $"$ & $"$ & 13 & 16.7 & 11 & 13.1 \\
\hline \multicolumn{9}{|l|}{$\overline{\mathrm{AOA}}$} \\
\hline & & 40 & 125 & -2 & 8.5 & 5.0 & 5.0 & 3.4 \\
\hline & 15 & 160 & 6 & -2 & 18 & 21.0 & 7.5 & 7.8 \\
\hline & 12 & 6 & $"$ & 0 & 13 & 16.0 & 11 & 12.5 \\
\hline & 16 & $" 3$ & 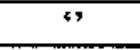 & +2 & 8 & 10.0 & 18 & 20.0 \\
\hline \multicolumn{9}{|l|}{ Airspeed } \\
\hline & 12 & 160 & 125 & 0 & 13 & 16.0 & 11 & 12.5 \\
\hline & 38 & $\because 3$ & 163 & 6 & 13 & & 11 & \\
\hline & 52 & " & 195 & 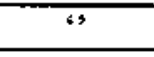 & 13 & 16.7 & 11 & 13.1 \\
\hline
\end{tabular}

Table 6. Effect of Angle-of-Attack on measured ice ridge height (MVD $=160 \mu \mathrm{m}$, Flap $=0^{\circ}$, Boot Cycle $=3 \mathrm{~min}$ )

\begin{tabular}{|c|c|c|c|c|c|c|c|}
\hline \multirow[t]{2}{*}{$\begin{array}{l}\text { Run } \\
\text { Number }\end{array}$} & \multirow[t]{2}{*}{$\begin{array}{l}\text { Airspeed } \\
\text { (mph) }\end{array}$} & \multirow[t]{2}{*}{$\begin{array}{c}\mathrm{T}_{\mathrm{t}} \\
\left({ }^{\circ} \mathrm{F}\right)\end{array}$} & \multirow[t]{2}{*}{$\begin{array}{l}\text { Angle-of Attack } \\
\text { (degrees) }\end{array}$} & \multicolumn{2}{|c|}{$\begin{array}{l}\text { Suction Surface } \\
\text { Ridge Height } \\
\text { (inches) }\end{array}$} & \multicolumn{2}{|c|}{$\begin{array}{l}\text { Pressure Surface } \\
\text { Ridge Height } \\
\text { (inches) }\end{array}$} \\
\hline & & & & $\max$ & $\min$ & $\max$ & $\min$ \\
\hline $49 a$ & 195 & 32 & -2 & .66 & .43 & .51 & .43 \\
\hline 43 & $"$ & $"$ & 0 & .62 & .40 & .39 & .25 \\
\hline $50 \mathrm{a}$ & $"$ & $"$ & +2 & .78 & .32 & .36 & .24 \\
\hline 9 & 125 & 30 & -2 & .62 & .39 & .31 & .26 \\
\hline 4 & $"$ & $"$ & 0 & .42 & .30 & .33 & .19 \\
\hline 10 & $"$ & $"$ & +2 & .45 & .30 & .56 & .29 \\
\hline 11 & $"$ & $"$ & +4 & .36 & .32 & .55 & .19 \\
\hline
\end{tabular}


Table 7. Effect of flap setting on measured ice ridge height

(MVD $=160 \mu \mathrm{m}, \mathrm{V}=125 \mathrm{mph}, \mathrm{AOA}=0^{\circ}$, Boot Cycle=3min)

\begin{tabular}{|c|c|c|c|c|c|c|}
\hline \multirow[t]{2}{*}{$\begin{array}{c}\text { Run } \\
\text { Number }\end{array}$} & \multirow[t]{2}{*}{$\begin{array}{c}T_{t} \\
\left({ }^{\circ} F\right)\end{array}$} & \multirow[t]{2}{*}{$\begin{array}{c}\text { Flap Setting } \\
\text { (degrees) }\end{array}$} & \multicolumn{2}{|c|}{$\begin{array}{l}\text { Suction Surface Ridge } \\
\text { Height (inches) }\end{array}$} & \multicolumn{2}{|c|}{$\begin{array}{c}\text { Pressure Surface Ridge } \\
\text { Height (inches) }\end{array}$} \\
\hline & & & $\max$ & $\min$ & $\max$ & $\min$ \\
\hline 4 & 30 & 0 & .42 & .30 & .33 & .19 \\
\hline 64 & $"$ & 10 & .59 & .33 & .42 & .30 \\
\hline 70 & $"$ & 20 & .48 & .37 & .40 & .34 \\
\hline 5 & 28 & 0 & .54 & .43 & .50 & .38 \\
\hline 65 & $"$ & 10 & .71 & .60 & .54 & .32 \\
\hline 71 & $"$ & 20 & .78 & .19 & .49 & .39 \\
\hline
\end{tabular}




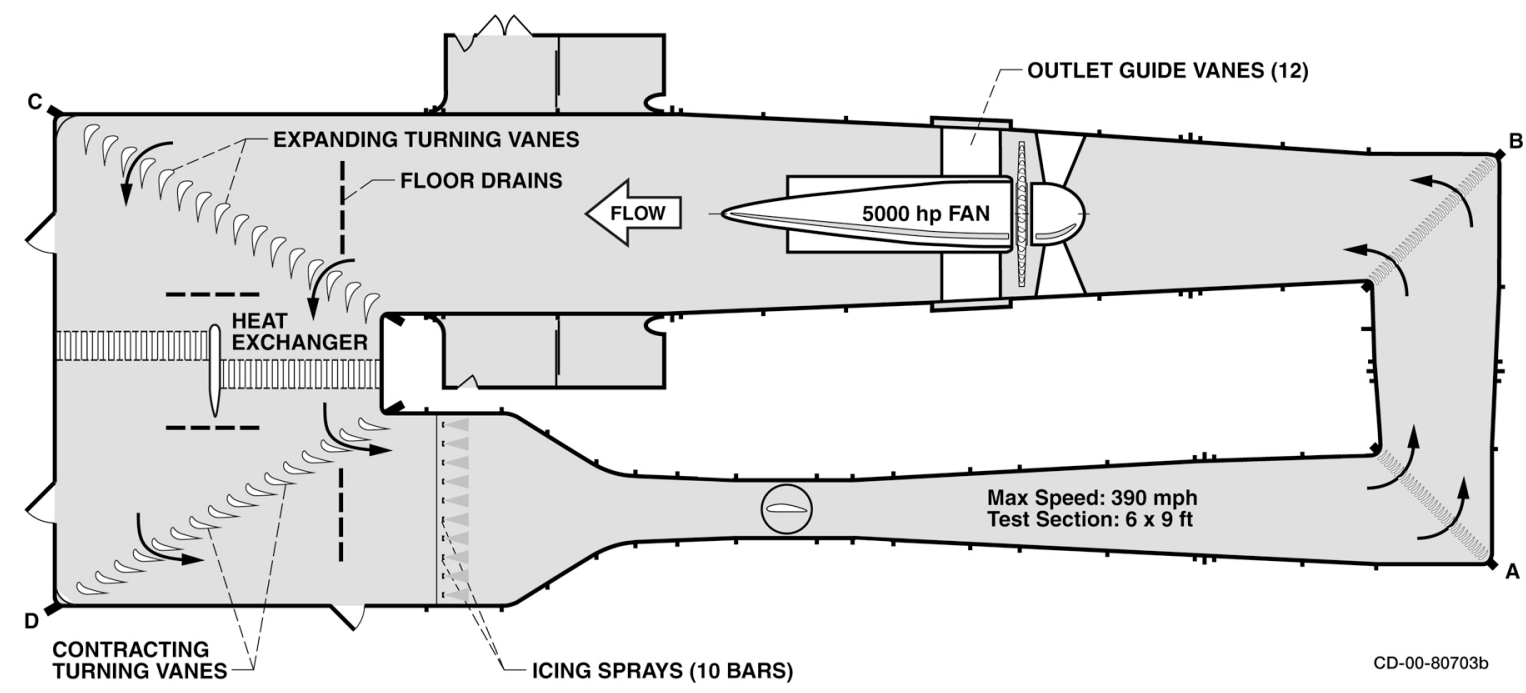

Figure 1 - Plan view of Icing Research Tunnel.

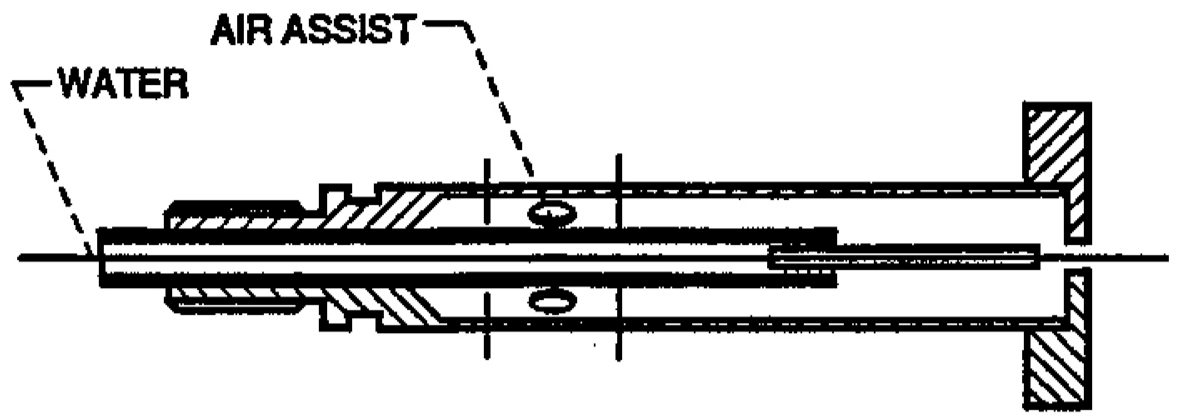

\begin{tabular}{|ll|}
\hline WATER TUBE DIAMETER \\
\hline NOZZLE & TUBE I.D. \\
\hline STANDARD & 0.025 in. \\
MOD - 1 & 0.0155 in. \\
\hline
\end{tabular}

Figure 2 - Icing Research Tunnel spray bar nozzle. 


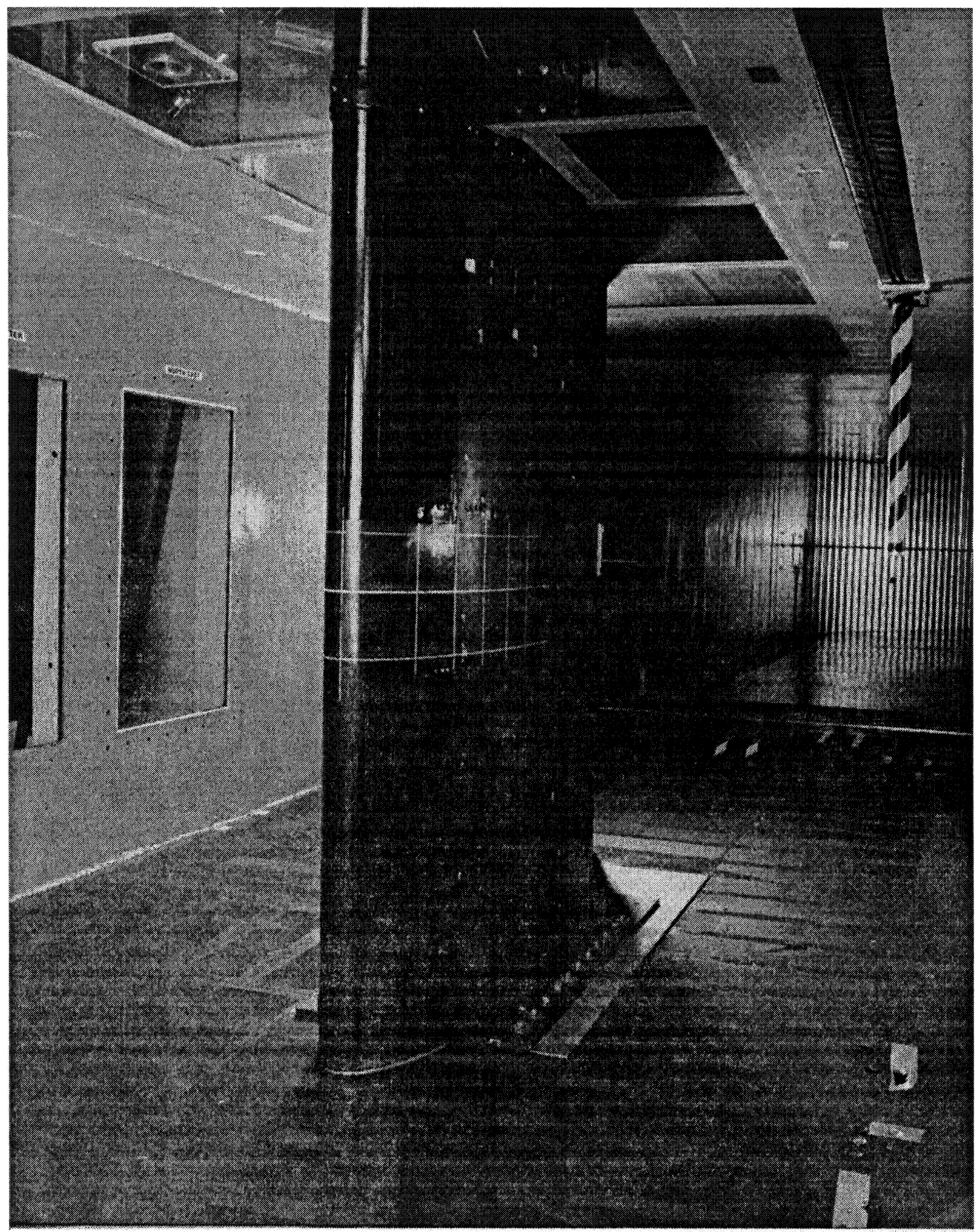

Figure 3 - Twin Otter wing section installed in Icing Research Tunnel. 


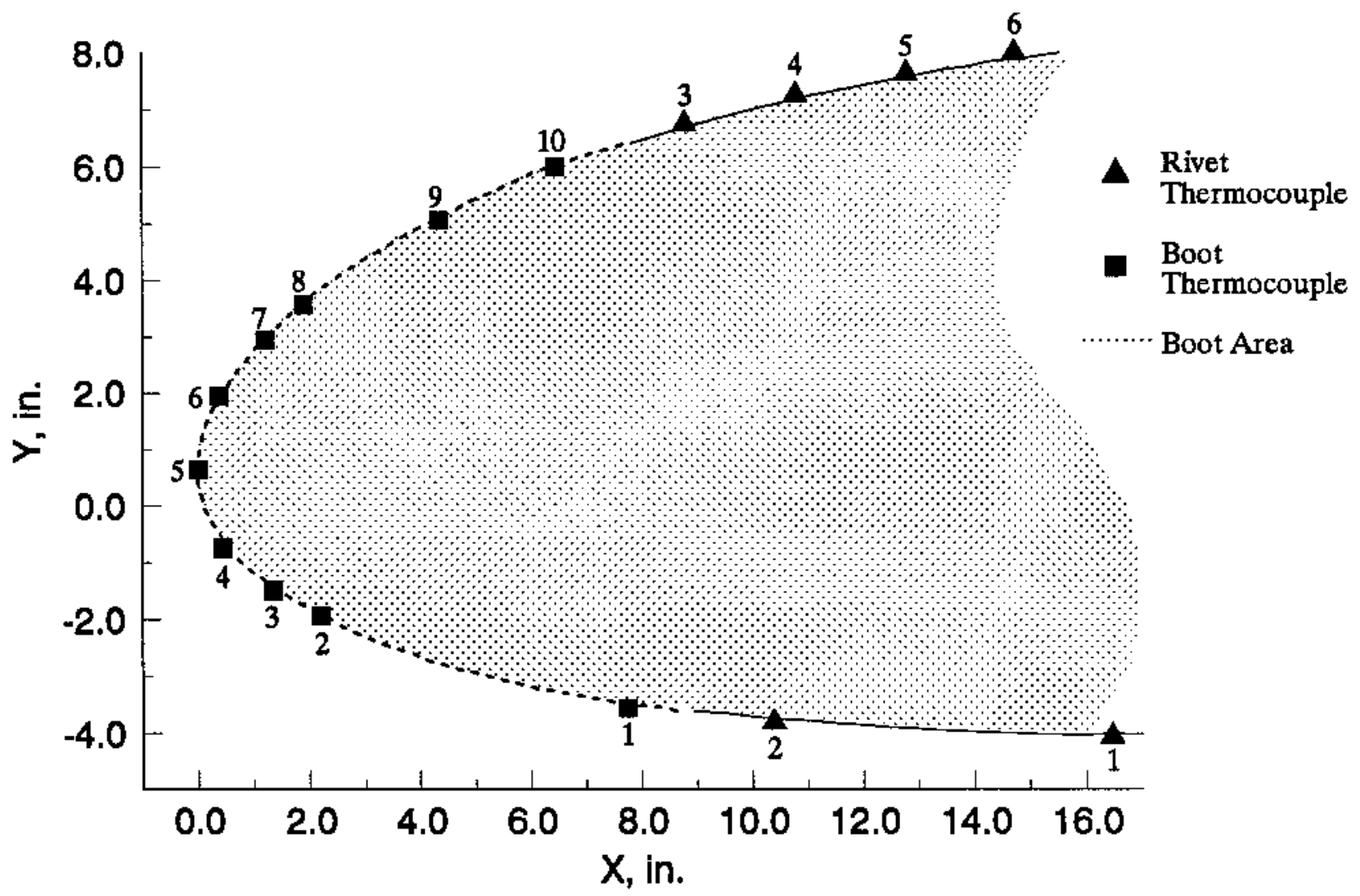

Note: Boot thermocouples are located at spanwise STA $=42^{\text {*t }}$

Rivet thermocouples are located at spanwise STA $=41.75^{\prime \prime}$

Model midspan STA $=36^{\prime \prime}$, Leading Edge $(0,0)$.

Figure 4 - Thermocouple locations on Twin Otter wing section. 


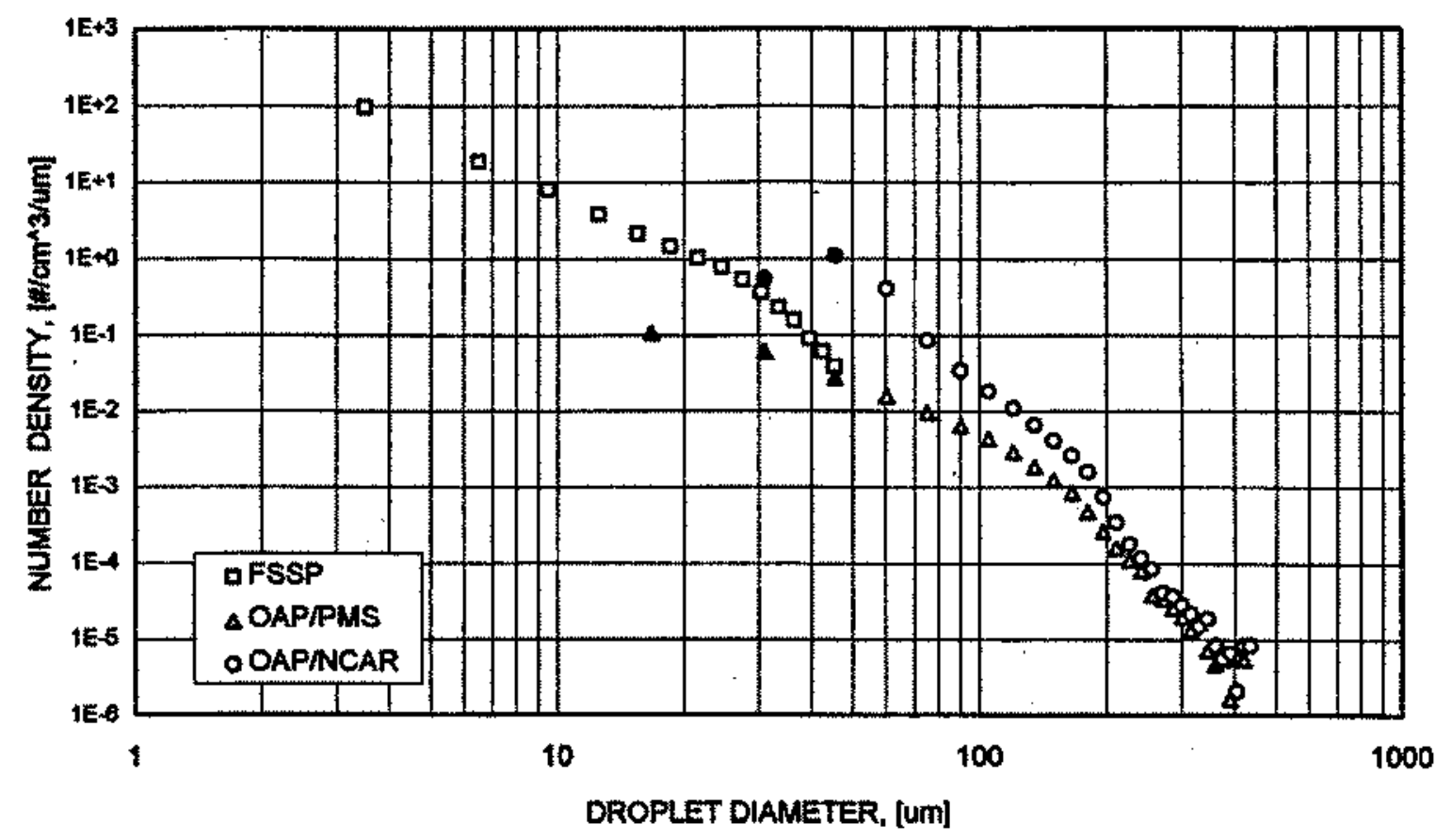

a). Number density distribution (air pressure $=6 \mathrm{psig}$, water pressure $=36 \mathrm{psig}$ )

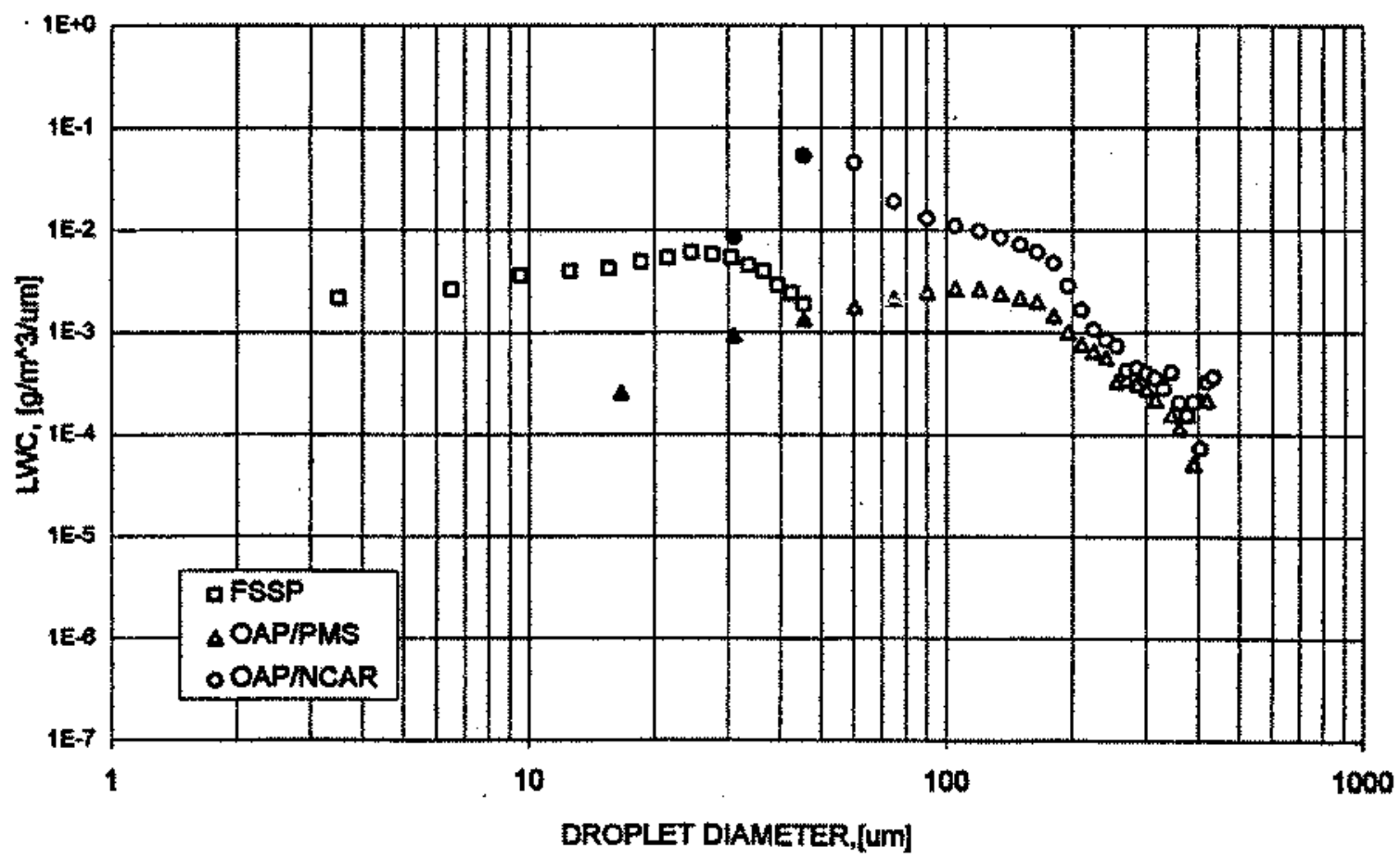

b). LWC distribution (air pressure $=6 \mathrm{psig}$, water pressure $=36 \mathrm{psig}$ )

Figure 5 - Comparison of droplet distributions using NCAR and PMS methods. 


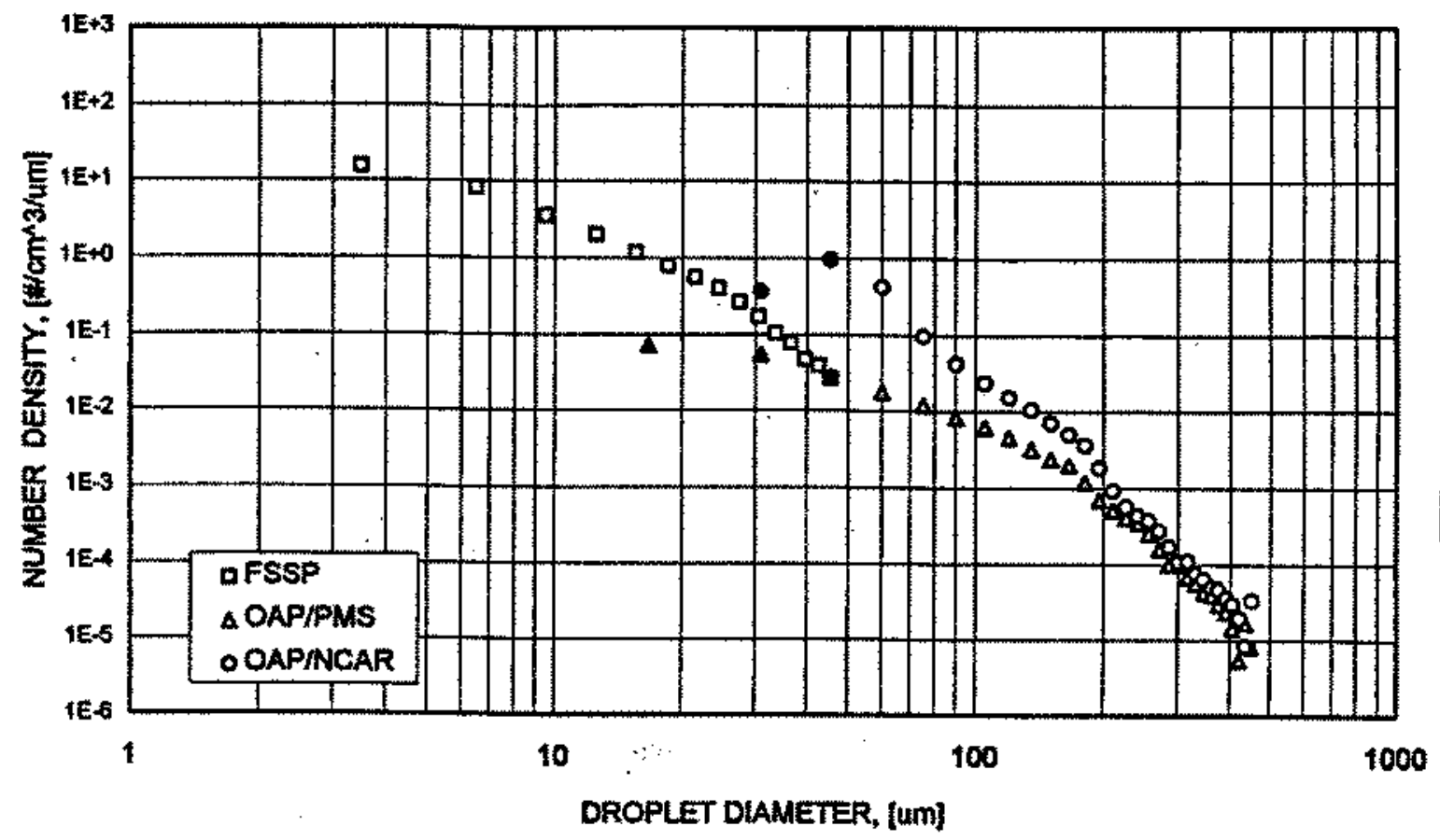

c). Number density distribution (air pressure $=\mathbf{5}$ psig, water pressure $\mathbf{= 5 5} \mathbf{p s i g}$ )

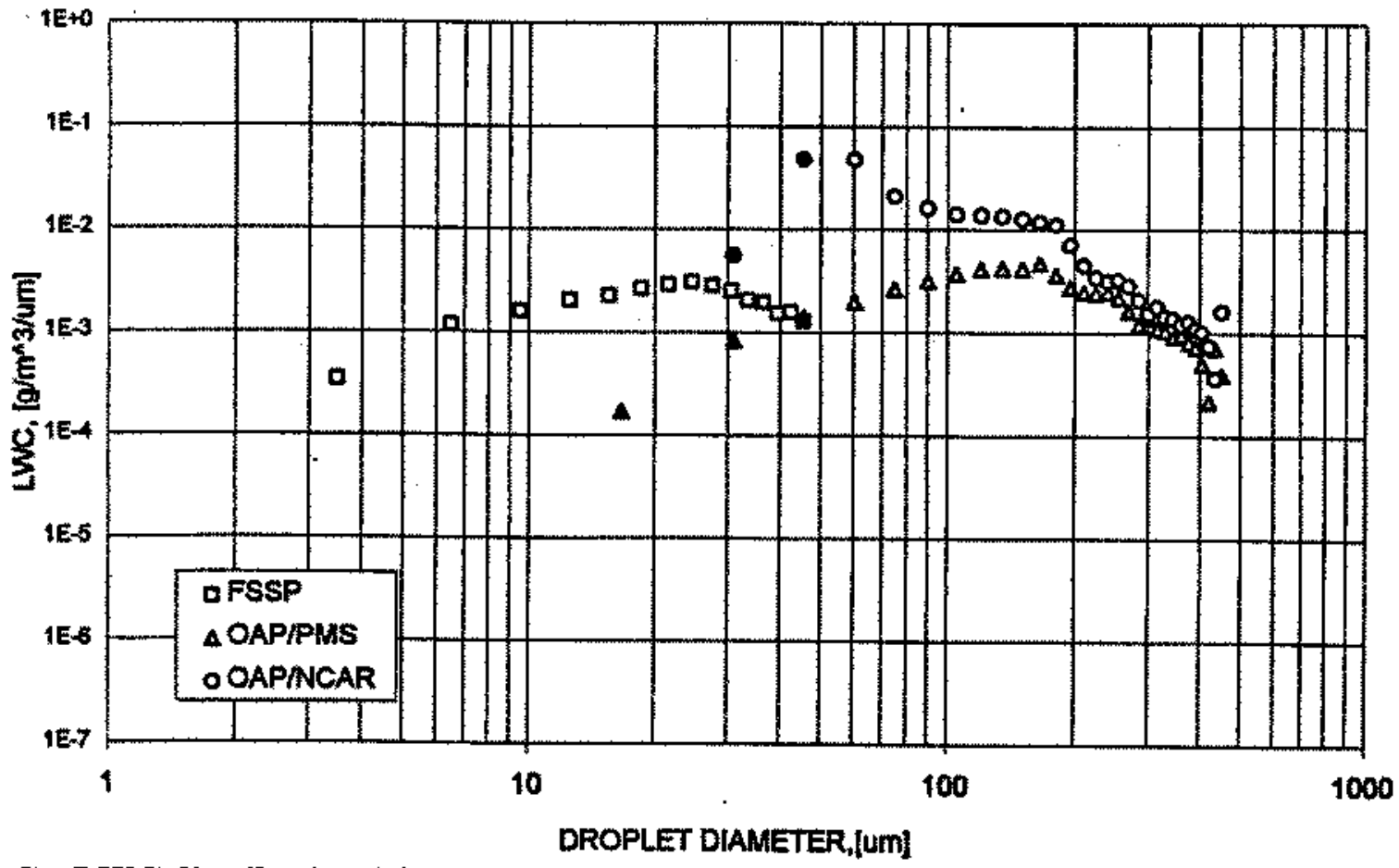

d). $\mathbf{L W C}$ distribution (air pressure $=5 \mathrm{psig}$, water pressure $=\mathbf{5 5} \mathrm{psig}$ )

Figure 5 - Comparison of droplet distributions using NCAR and PMS methods (concluded). 


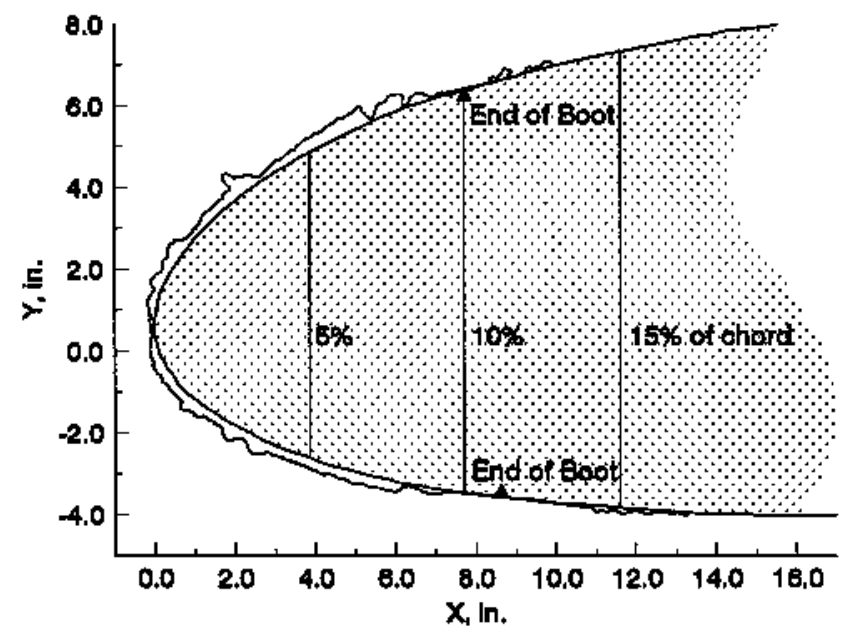

a). Spray bar water tamperature $=72^{\circ} \mathrm{F}$

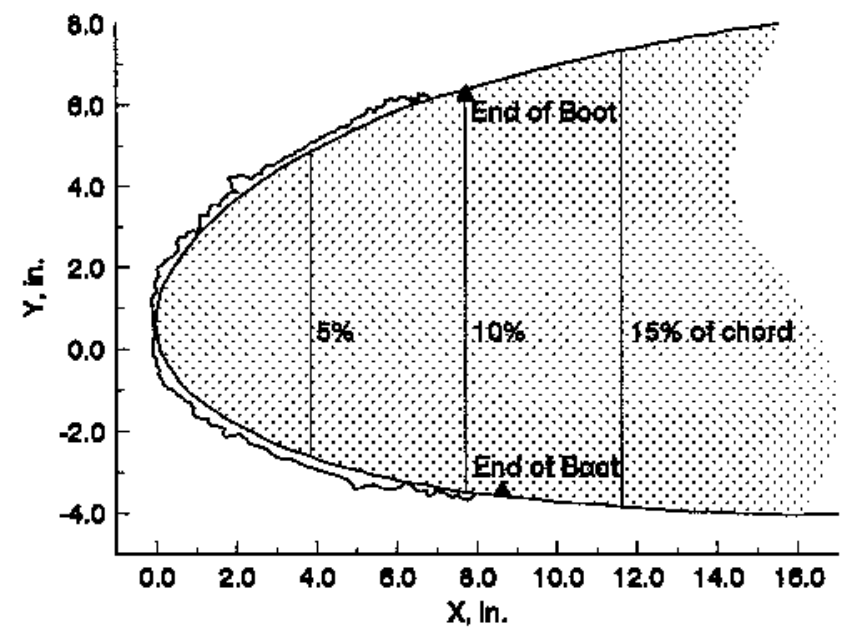

b). Spray bar water temperature $=100^{\circ} \mathrm{F}$

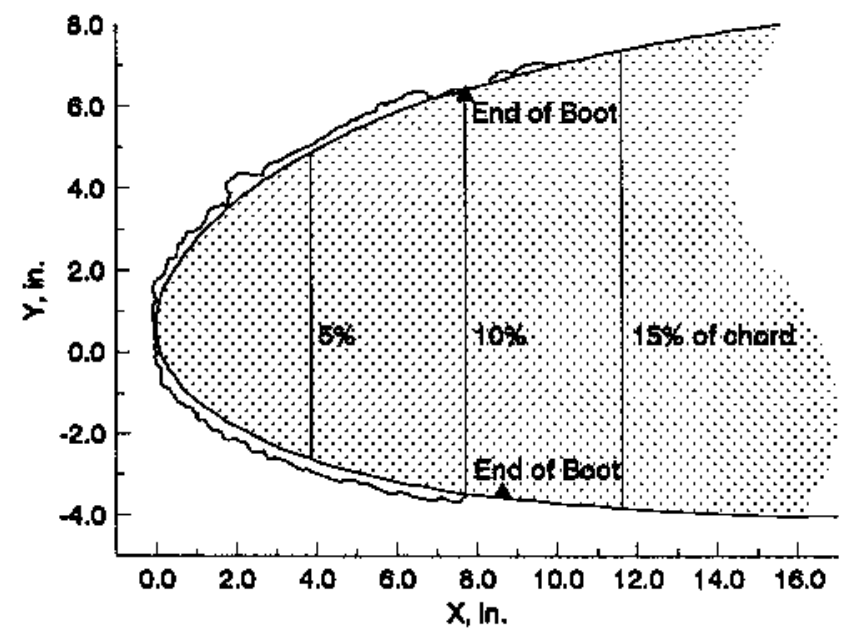

c). Spray bar water temperature $=185^{\circ} \mathrm{F}$

Figure 6 - Large droplet ice shape comparison with spray bar water temperature varied. $\left(\mathrm{Tt}=28^{\circ} \mathrm{F}, \mathrm{MVD}=160 \mu \mathrm{m}, \mathrm{LWC}=0.82 \mathrm{~g} / \mathrm{m}^{3}\right.$, $A O A=0^{\circ}, \mathrm{V}=195 \mathrm{mph}$, Flap $=0^{\circ}$, Boot Cycle $=$ none, Spray $=18 \mathrm{~min}$.) 


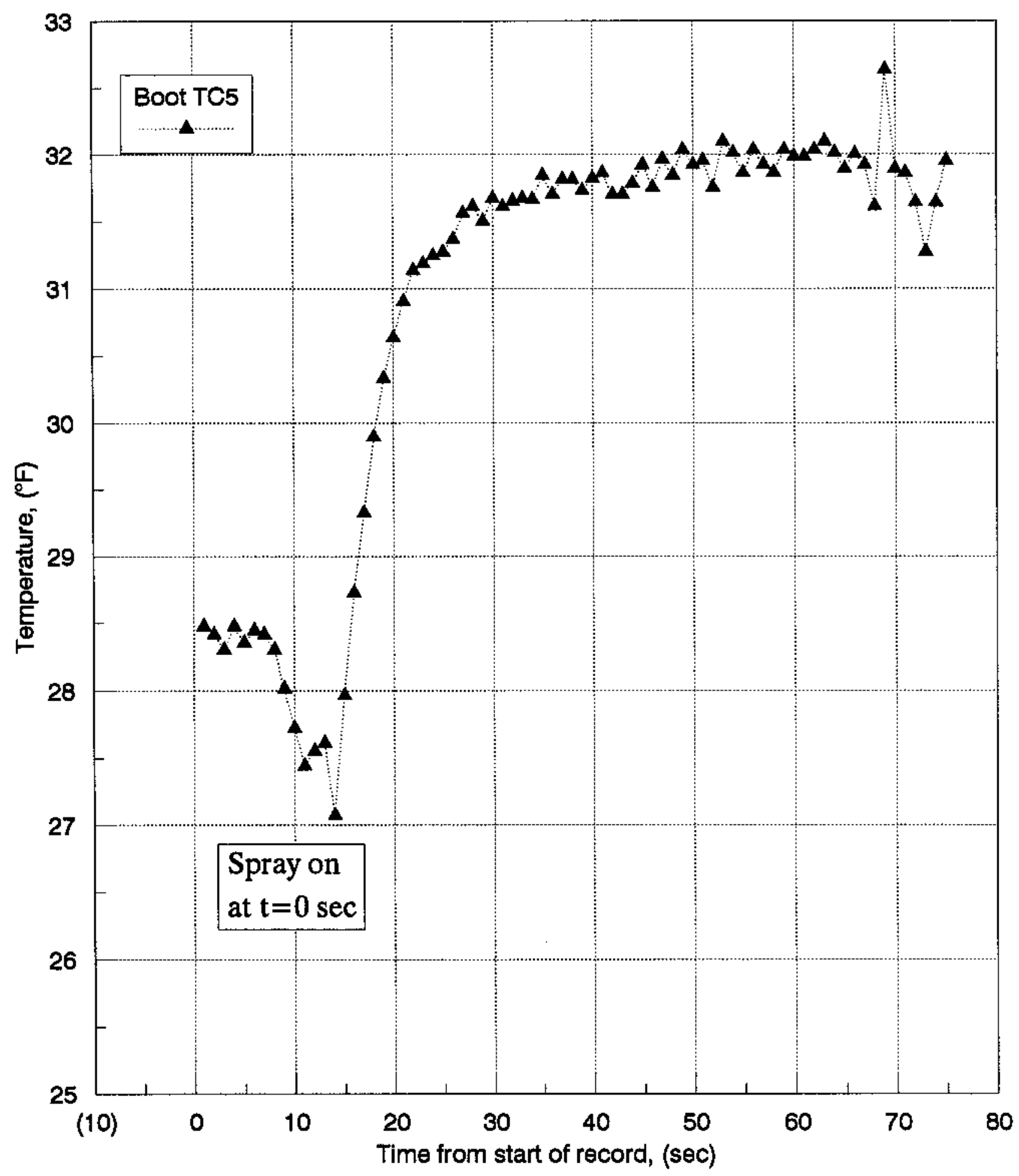

Figure 7 - Leading-Edge temperature after initiation of large droplet icing spray. (Tt $=28^{\circ} \mathrm{F}, \mathrm{V}=195 \mathrm{mph}, \mathrm{MVD}=160 \mu \mathrm{m}, \mathrm{LWC}=0.82 \mathrm{~g} / \mathrm{m}^{3}, \mathrm{AOA}=0^{\circ}, \mathrm{Flap}=0^{\circ}$ ) 


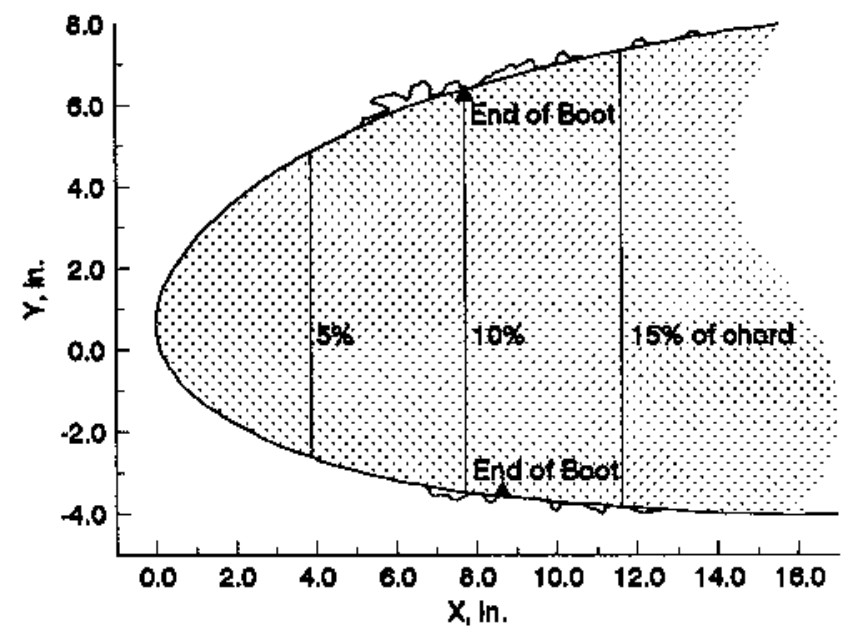

a). Run 43, STA 38 tracing

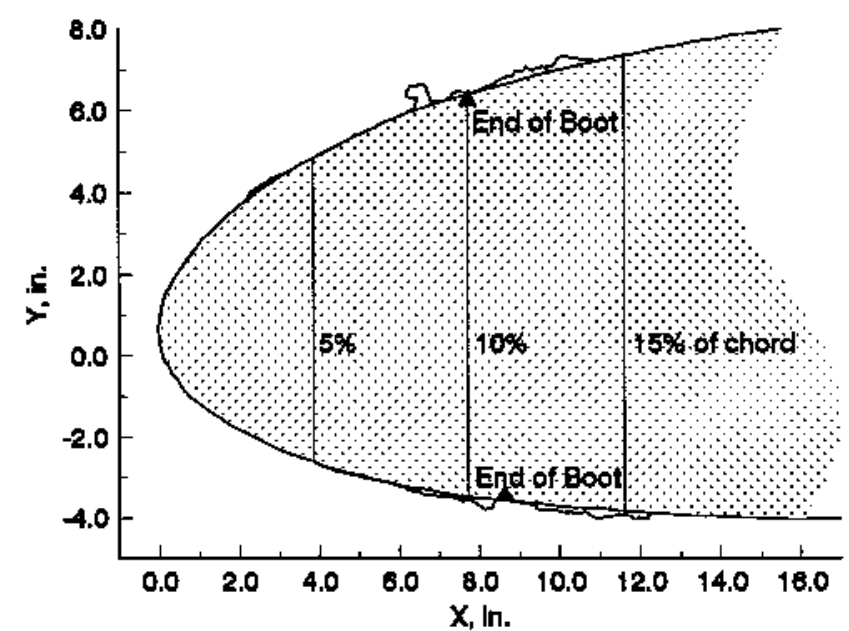

b). Run 43-r, STA 39 tracing

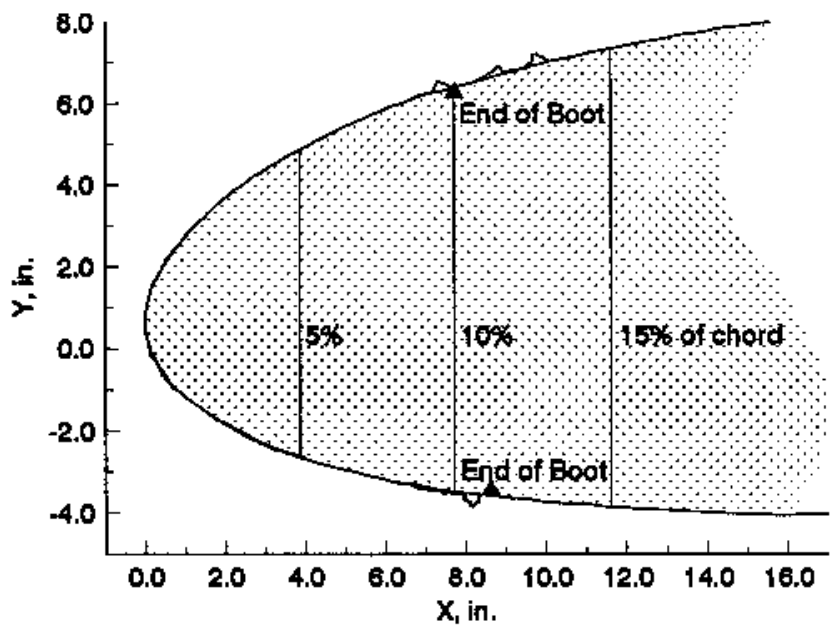

c). Run 43-r3, STA 36 tracing

Figure 8 - Run-to-run repeatability of large droplet ice accretions. $\left(\mathrm{Tt}=32^{\circ} \mathrm{F}, \mathrm{MVD}=160 \mu \mathrm{m}, \mathrm{LWC}=0.82 \mathrm{~g} / \mathrm{m}^{3}, \mathrm{AOA}=0^{\circ}, \mathrm{V}=195 \mathrm{mph}\right.$, Flap $=0^{\circ}$, Boot Cycle = 3 min., Spray $=18 \mathrm{~min}$.) 


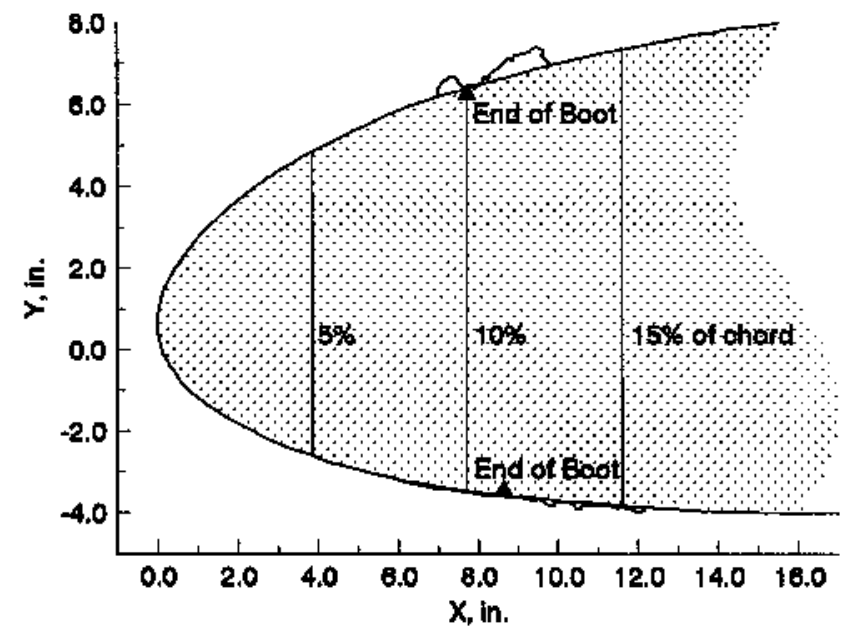

a). Run 43a, STA 38 tracing

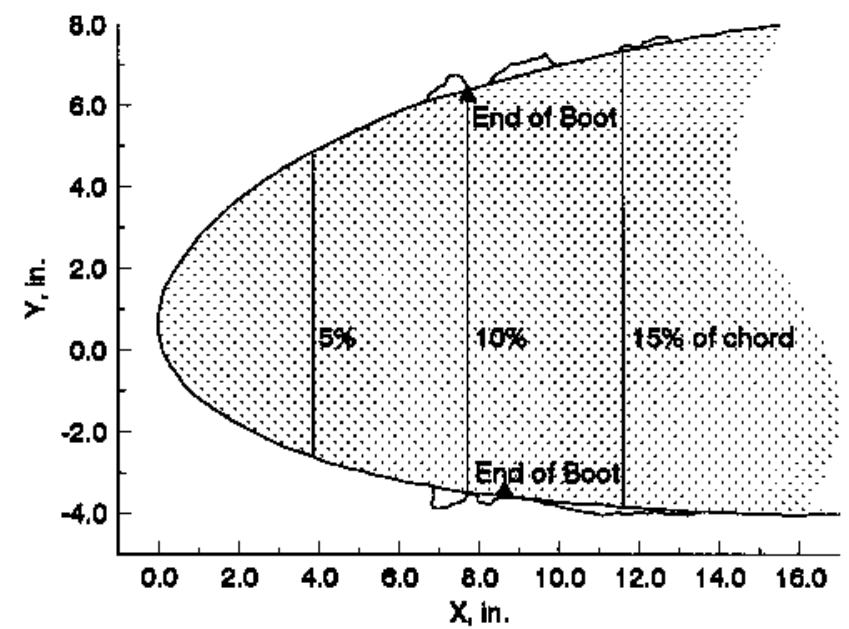

b). Run 43a-r, STA 36 tracing

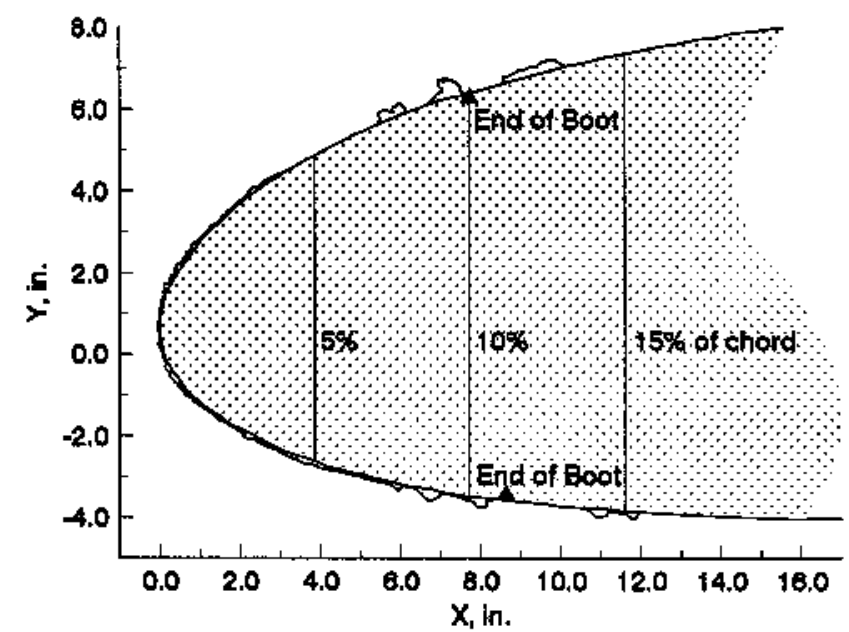

c). Run $43 a-r 2$, STA 36 tracing

Figure 9 - Run-to-run repeatability of large droplet ice accretions. $\left(\mathrm{Tt}=31^{\circ} \mathrm{F}, \mathrm{MVD}=160 \mu \mathrm{m}, \mathrm{LWC}=0.82 \mathrm{~g} / \mathrm{m}^{3}, \mathrm{AOA}=0^{\circ}, \mathrm{V}=195 \mathrm{mph}\right.$, Flap $=0^{\circ}$, Boot Cycle = 3 min., Spray = $18 \mathrm{~min}$.) 


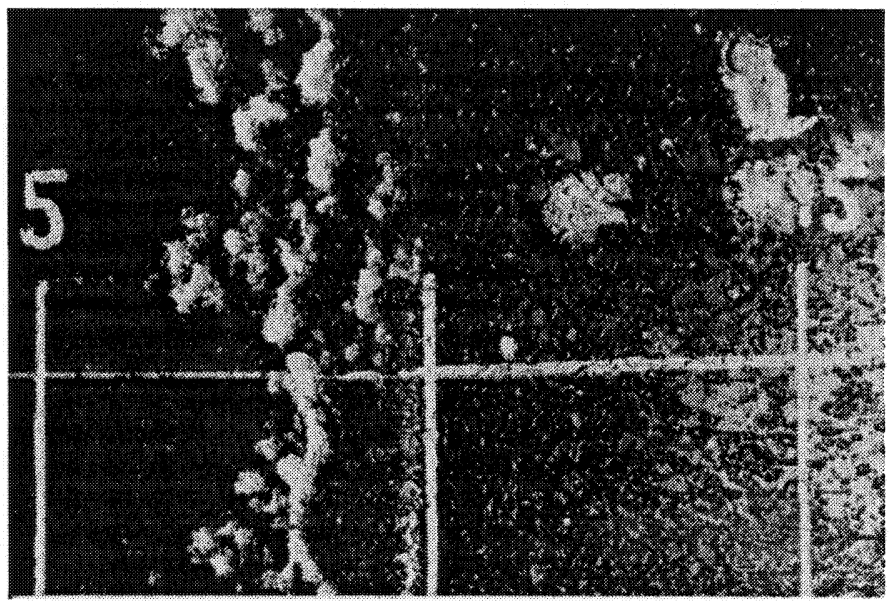

a). Run $3, T_{t}=32^{\circ} \mathrm{F}, \mathrm{V}=125 \mathrm{mph}$

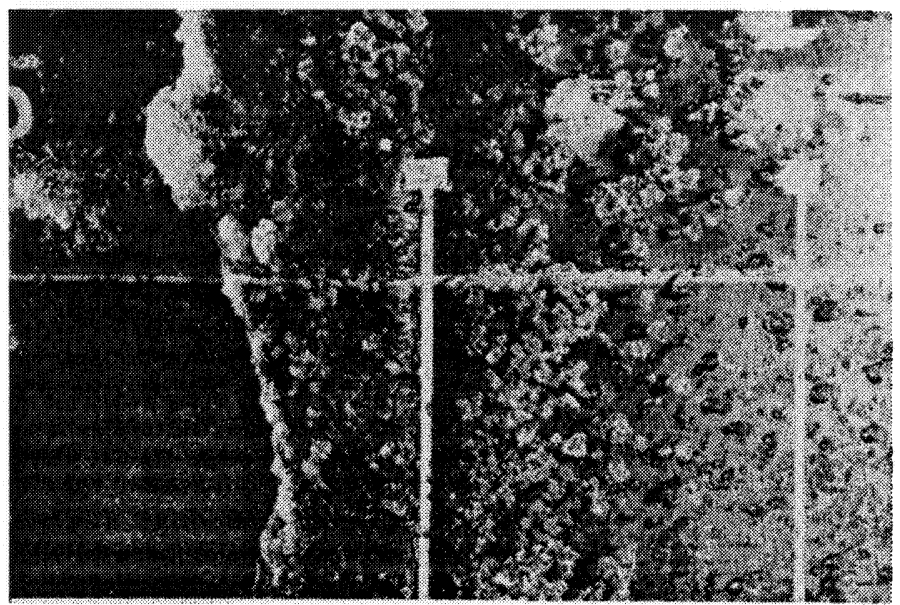

b). Run $4, T_{t}=30^{\circ} \mathrm{F}, \mathrm{V}=125 \mathrm{mph}$

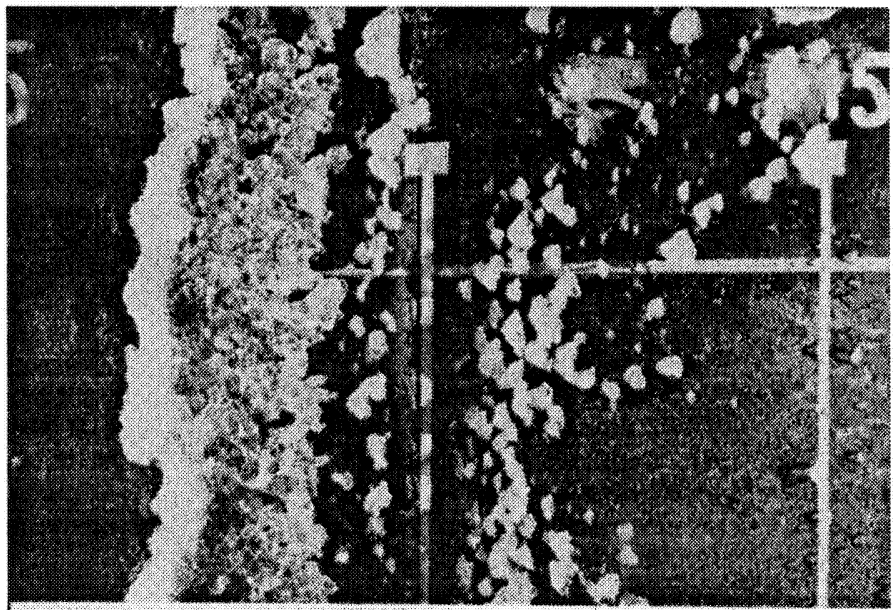

c). Run $5, \mathrm{~T}_{\mathrm{t}}=28^{\circ} \mathrm{F}, \mathrm{V}=125 \mathrm{mph}$

Figure 10 - Effect of total temperature on large droplet ice accretion $\left(\mathrm{V}=125 \mathrm{mph}, \mathrm{MVD}=160 \mu \mathrm{m}, \mathrm{LWC}=1.36 \mathrm{~g} / \mathrm{m}^{3}, \mathrm{AOA}=0^{\circ}, \mathrm{Flap}=0^{\circ}\right.$, Boot Cycle = 3 min., Spray = 18 min.) 


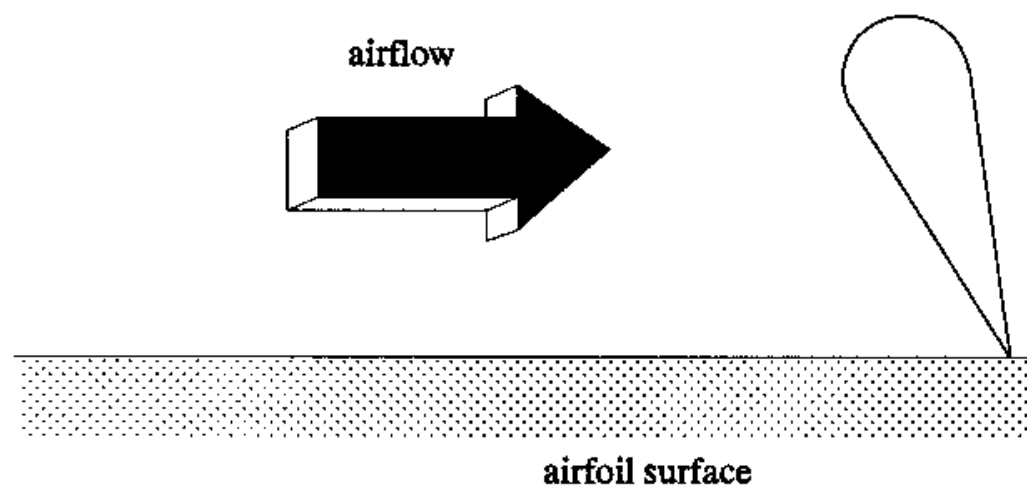

Figure 11 - Sketch of typical nodule. 


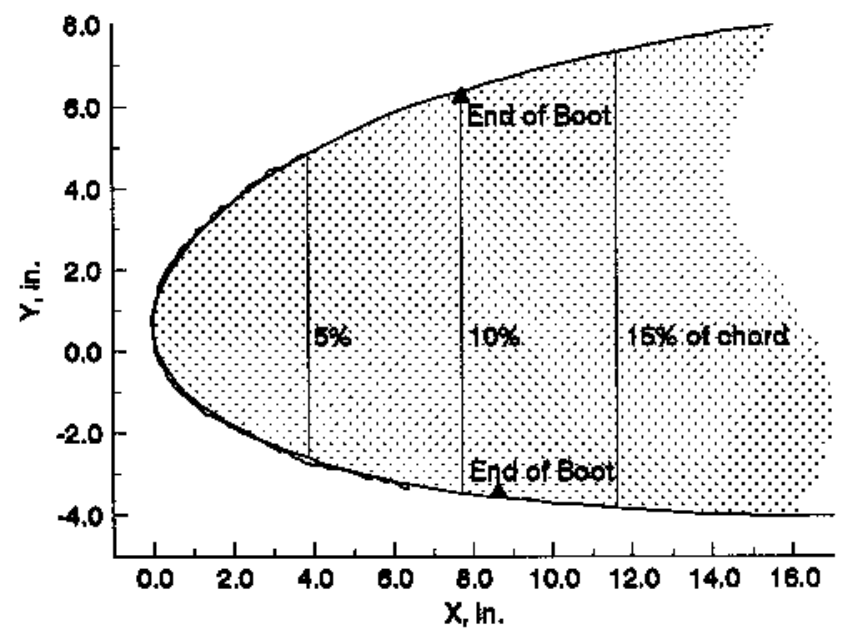

a). $M V D=40,1 \mathrm{~m}, \mathrm{LWC}=0.76 \mathrm{~g} / \mathrm{m}^{3}$

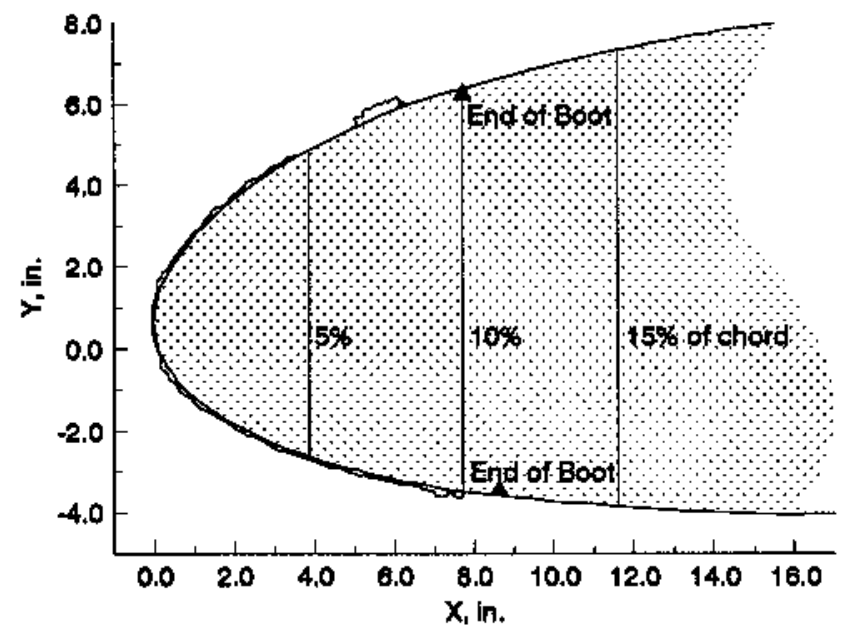

b). $M V D=8 q u m, L W C=0.85 \mathrm{~g} / \mathrm{m}^{3}$

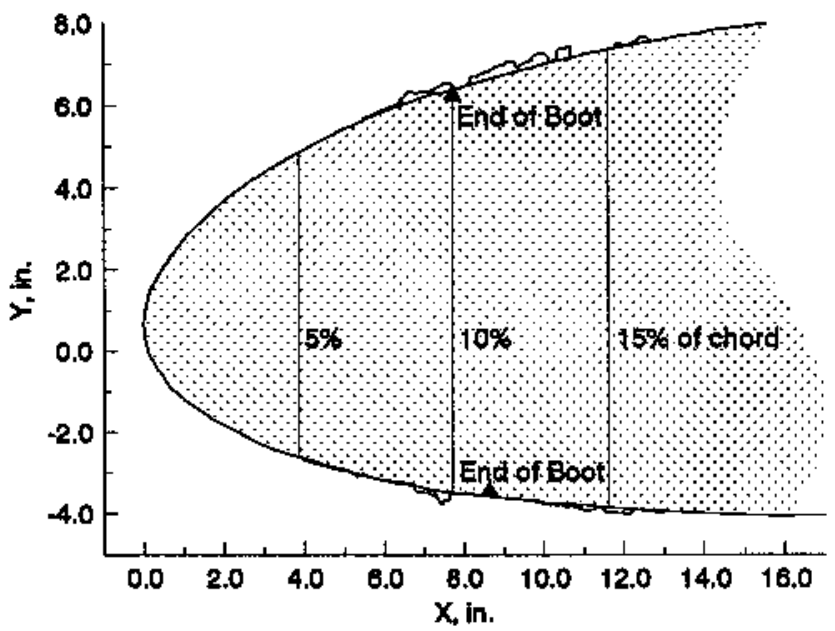

c). $M V D=160 \mu \mathrm{m}, L W C=1.30 \mathrm{~g} / \mathrm{m}^{3}$

Figure 12 - Droplet size effect.

$\left(\mathrm{Tt}=30^{\circ} \mathrm{F}, \mathrm{AOA}=0^{\circ}, \mathrm{V}=125 \mathrm{mph}\right.$, Flap $=0^{\circ}$, Boot Cycle $=3 \mathrm{~min} .$, Spray $=18 \mathrm{~min}$.) 

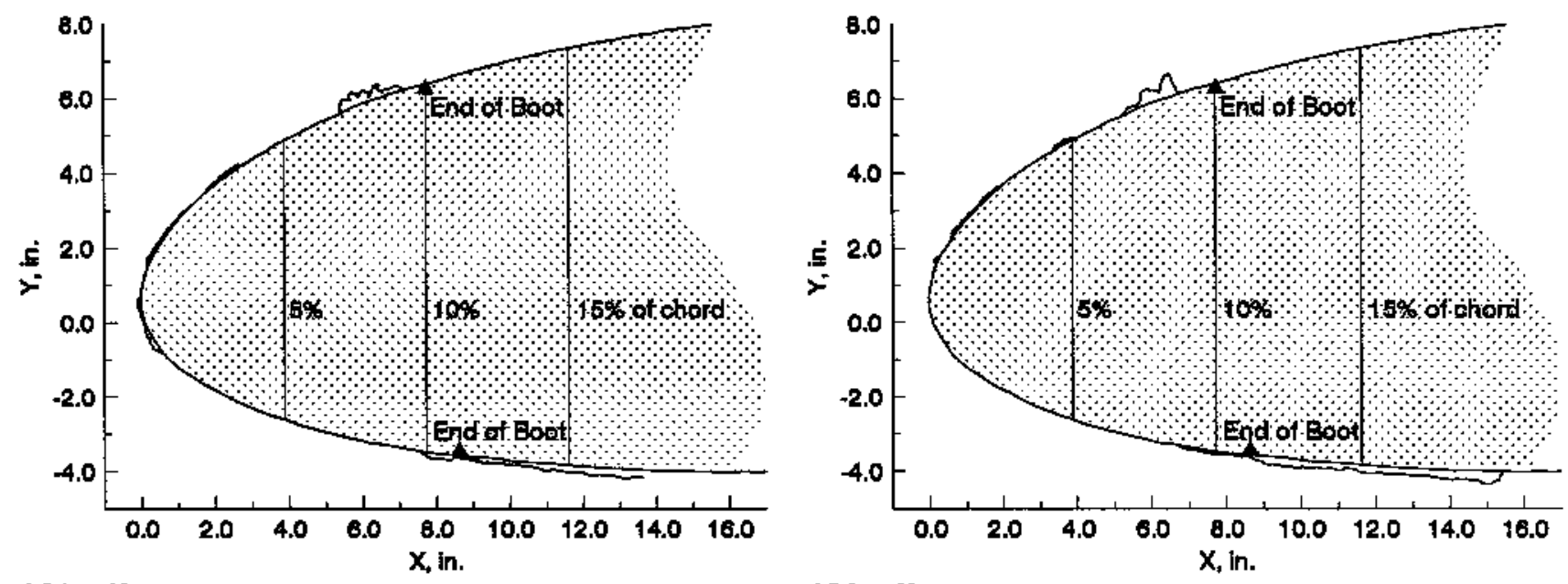

$A O A=2^{\circ}$

$A O A=2^{\circ}$
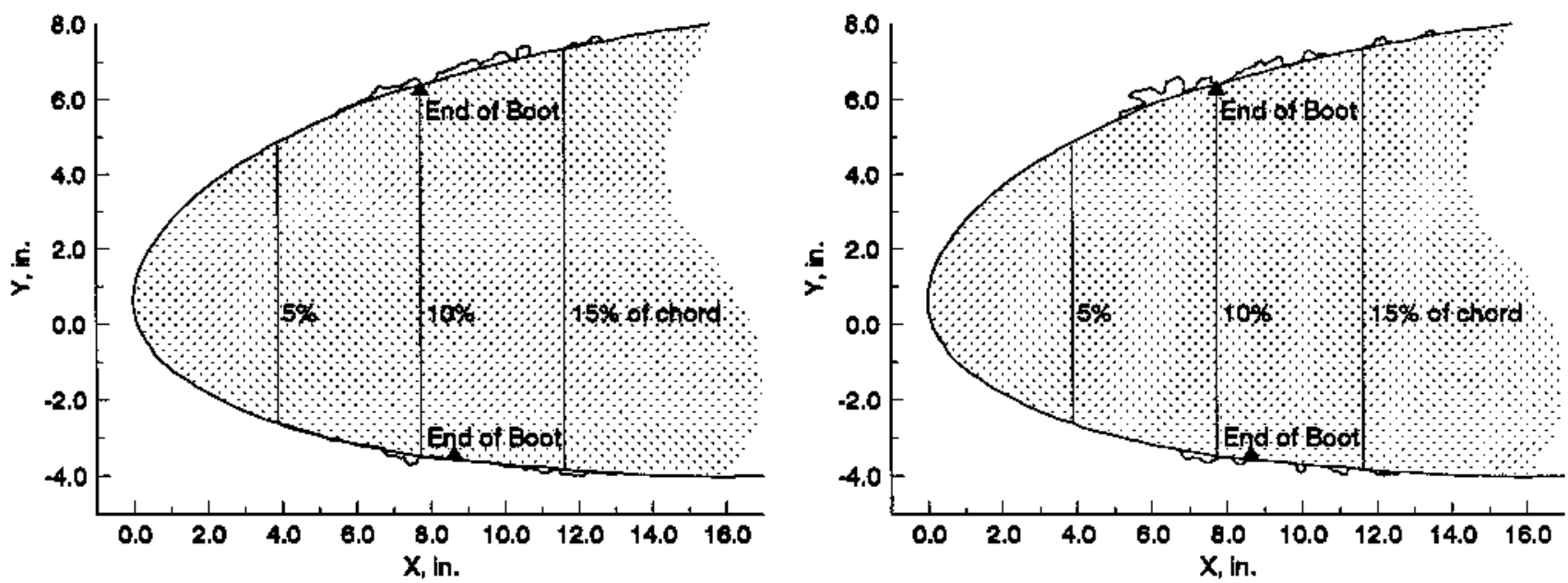

$A O A=0^{\circ}$

$\mathrm{AOA}=0^{\circ}$

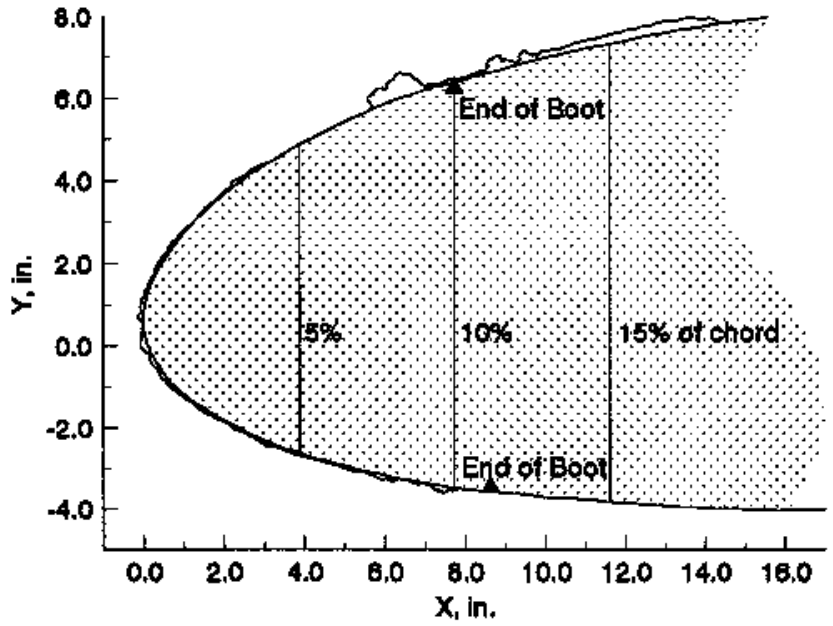

$A O A=-2^{\circ}$

a). $\mathrm{V}=125 \mathrm{mph}, \mathrm{Tt}=30^{\circ} \mathrm{F}, \mathrm{LWC}=1.36 \mathrm{~g} / \mathrm{m}^{3}$

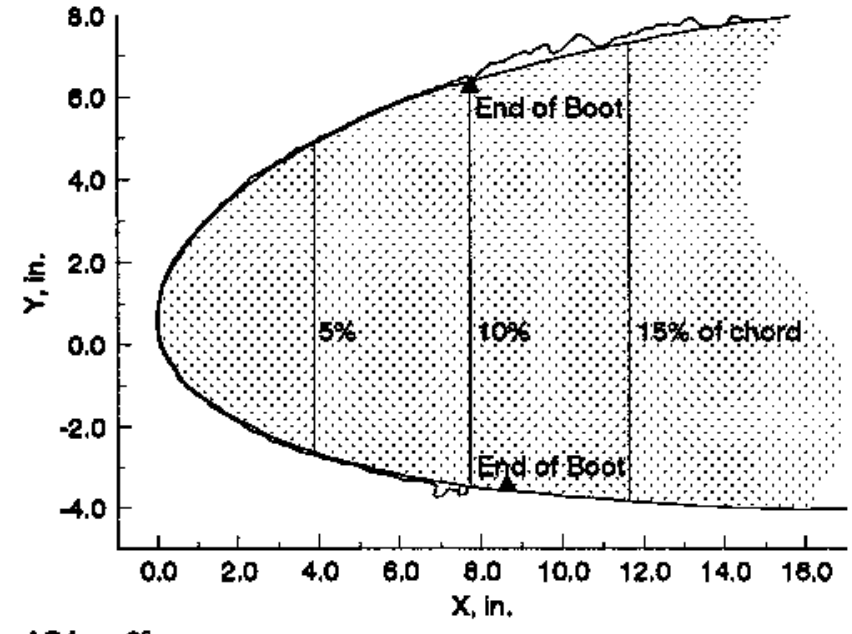

$A O A=-2^{\circ}$

b). $\mathrm{V}=195 \mathrm{mph}, \mathrm{Tt}=32^{\circ} \mathrm{F}, \mathrm{LWC}=0.82 \mathrm{~g} / \mathrm{m}^{3}$

Figure 13 - AOA effect.

$$
\left(\mathrm{MVD}=160 \mu \mathrm{m}, \text { Flap }=0^{\circ}, \text { Boot Cycle }=3 \mathrm{~min} ., \text { Spray }=18 \mathrm{~min} .\right)
$$




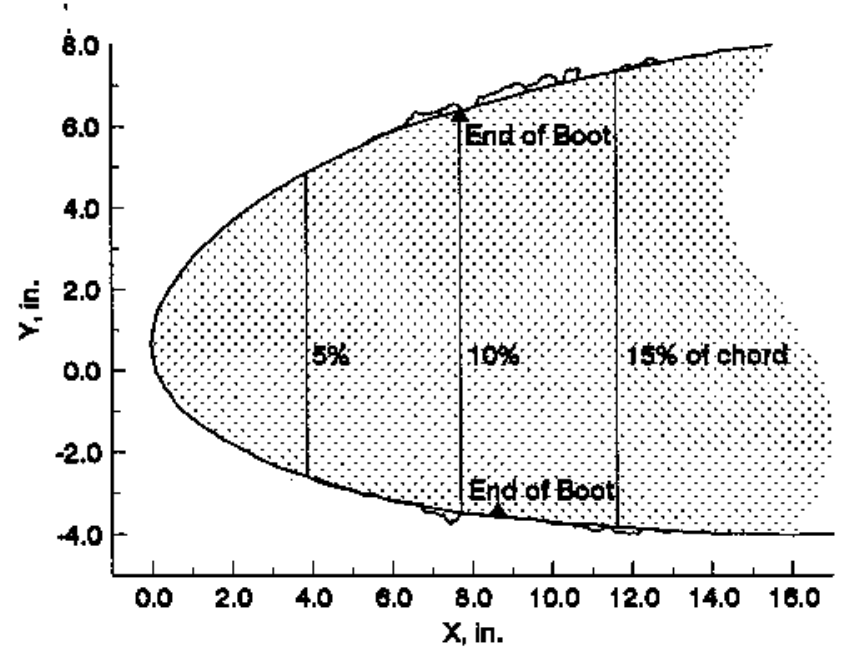

a). Flap $=\infty$

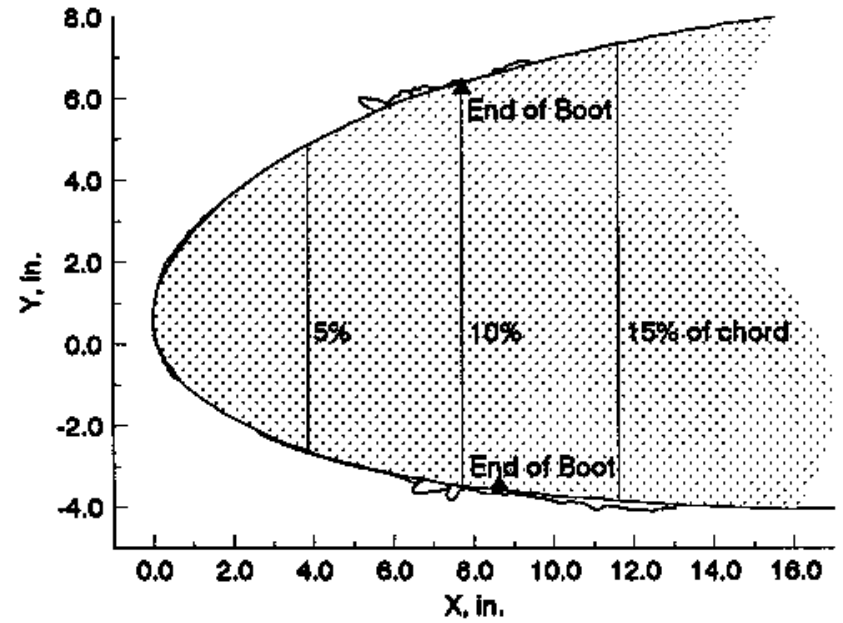

b). Flap $=10^{\circ}$

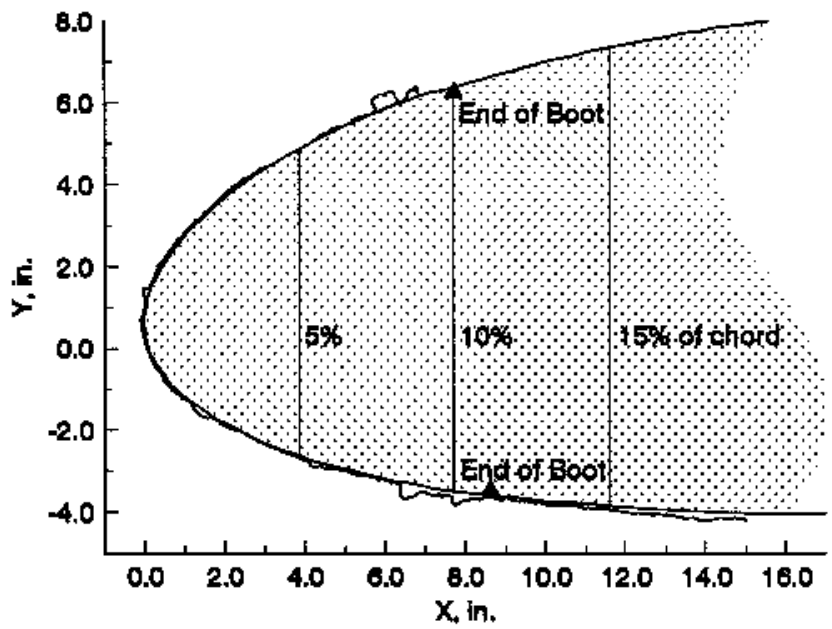

c). Flap $=20^{\circ}$

Figure 14 - Effect of flap setting on large droplet ice accretion.

$\left(\mathrm{Tt}=30^{\circ} \mathrm{F}, \mathrm{MVD}=160 \mu \mathrm{m}, \mathrm{AOA}=0^{\circ}, \mathrm{V}=125 \mathrm{mph}\right.$, Boot Cycle $=3 \mathrm{~min} .$, Spray=18 $\mathrm{min}$.) 
Public reporting burden for this collection of information is estimated to average 1 hour per response, including the time for reviewing instructions, searching existing data sources, gathering and maintaining the data needed, and completing and reviewing the collection of information. Send comments regarding this burden estimate or any other aspect of this collection of information, including suggestions for reducing this burden, to Washington Headquarters Services, Directorate for Information Operations and Reports, 1215 Jefferson Davis Highway, Suite 1204, Arlington, VA 22202-4302, and to the Office of Management and Budget, Paperwork Reduction Project (0704-0188), Washington, DC 20503.

\begin{tabular}{|l|l|l|}
\hline 1. AGENCY USE ONLY (Leave blank) & $\begin{array}{c}\text { 2. REPORT DATE } \\
\text { June } 2005\end{array}$ & $\begin{array}{r}\text { 3. REPORT TYPE AND DATES COVERED } \\
\text { Technical Memorandum }\end{array}$ \\
\hline
\end{tabular}

4. TITLE AND SUBTITLE 5. FUNDING NUMBERS

A Study of Large Droplet Ice Accretions in the NASA Glenn IRT at Near-Freezing Conditions

6. AUTHOR(S)

WU-505-68-10

Dean R. Miller, Harold E. Addy, Jr., and Robert F. Ide

7. PERFORMING ORGANIZATION NAME(S) AND ADDRESS(ES)

National Aeronautics and Space Administration

John H. Glenn Research Center at Lewis Field

Cleveland, Ohio 44135-3191

8. PERFORMING ORGANIZATION REPORT NUMBER

E-10072-1

9. SPONSORING/MONITORING AGENCY NAME(S) AND ADDRESS(ES)

National Aeronautics and Space Administration

Washington, DC 20546-0001

10. SPONSORING/MONITORING AGENCY REPORT NUMBER

NASA TM-1996-107142-REV1

ARL-MR-294

AIAA-96-0934

11. SUPPLEMENTARY NOTES

Prepared for the 34th Aerospace Sciences Meeting and Exhibit sponsored by the American Society of Aeronautics and Astronautics, Reno, Nevada, January 15-18, 1996. Dean R. Miller and Harold E. Addy, Jr., NASA Glenn Research Center; and Robert F. Ide, U.S. Army Research Laboratory, NASA Glenn Research Center. Responsible person, Dean R. Miller, organization code RTI, 216-433-5349.

12a. DISTRIBUTION/AVAILABILITY STATEMENT 12b. DISTRIBUTION CODE

Unclassified - Unlimited

Subject Category: 03

Available electronically at http://gltrs.grc.nasa.gov

This publication is available from the NASA Center for AeroSpace Information, 301-621-0390.

13. ABSTRACT (Maximum 200 words)

This report documents the results of an experimental study on large droplet ice accretions which was conducted in the NASA Glenn Icing Research Tunnel (IRT) with a full-scale 77.25 inch chord Twin-Otter wing section. This study was intended to: (1) document the existing capability of the IRT to produce a large droplet icing cloud, and (2) study the effect of various parameters on large droplet ice accretions. Results are presented from a study of the IRT's capability to produce large droplets with MVD of 99 and $160 \mu \mathrm{m}$. The effect of the initial water droplet temperature on the resultant ice accretion was studied for different initial spray bar air and water temperatures. The initial spray bar water temperature was found to have no discernible effect upon the large droplet ice accretions. Also, analytical and experimental results suggest that the water droplet natural icing condition. The effect of temperature, droplet size, airspeed, angle-of-attack, flap setting and de-icer boot cycling time on ice accretion was studied, and will be discussed in this report. It was found that, in almost all of the cases studied, an ice ridge formed immediately aft of the active portion of the de-icer boot. This ridge was irregular in shape, varied in location, and was in some cases, discontinuous due to aerodynamic shedding.

14. SUBJECT TERMS 15. NUMBER OF PAGES

Supercooled large droplet icing; Aircraft hazards; Aeronautics 33

\begin{tabular}{|c|c|c|}
\hline $\begin{array}{c}\text { 17. SECURITY CLASSIFICATION } \\
\text { OF REPORT } \\
\text { Unclassified }\end{array}$ & $\begin{array}{c}\text { 18. SECURITY CLASSIFICATION } \\
\text { OF THIS PAGE } \\
\text { Unclassified }\end{array}$ & $\begin{array}{c}\text { 19. SECURITY CLASSIFICATION } \\
\text { OF ABSTRACT } \\
\text { Unclassified }\end{array}$ \\
\hline
\end{tabular}

NSN 7540-01-280-5500

Standard Form 298 (Rev. 2-89) 